\title{
The Combined Anti-inflammatory Strategy of Beta-2 Adrenergic Agonist and Glucocorticoid on the Laying Hen Model of Ovarian Cancer: the Immune Traits and Ovarian Inflammatory Functions
}

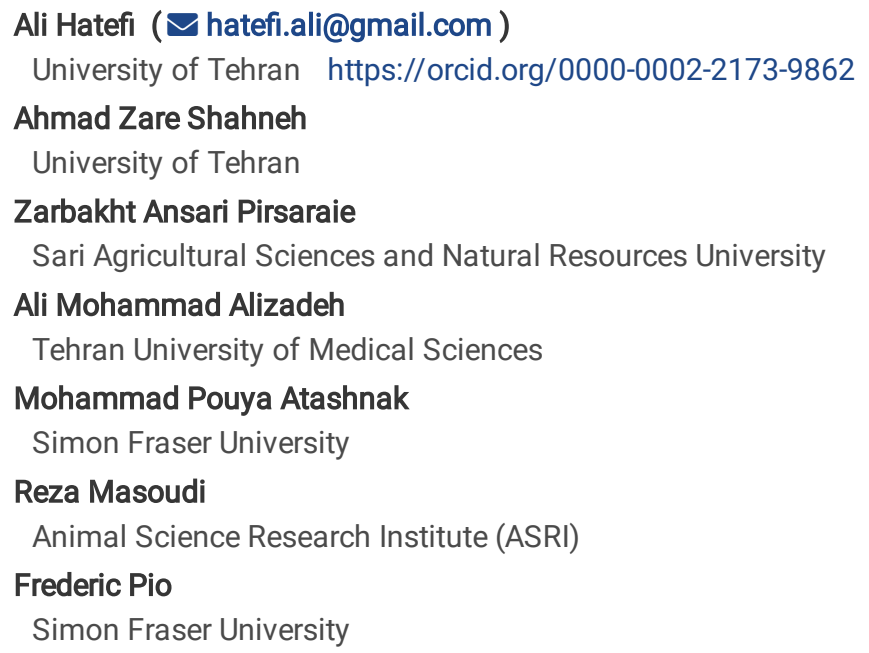




\section{Abstract}

Background: Ovarian cancer known as one of the most lethal gynecological malignancies mainly in older women, has been documented to link with chronic inflammation.

Objective: This study was aimed to evaluate the combined strategy of glucocorticoid (GC) Fluticasone and beta-2 adrenergic agonist (BAA) Salmeterol on the ovarian inflammatory functions of the laying hen as a model of women ovarian cancer.

Methods: White Leghorn hens aged 92 weeks were used for four weeks to be supplemented by individual of GC and BAA administration and their combination at three ratios GC:BAA 1:4 (GC+BAA1), 1:2 (GC+BAA2), and 1:1 (GC+BAA3), and beta blocker (BB) Propranolol. Ovulation rate and follicular growth were determined based on laying frequency and visual evaluation, respectively, the mRNA expressions of follicular beta-2 adrenergic receptor ( $\beta 2 A D R)$, cyclooxygenases (COX) 1 and 2, and cytokines were measured by real-time PCR. The plasma concentration of ovarian hormones cellular and humoral immune responses were measured via ELISA, neutrophil (heterophil) to lymphocyte ratio (NLR), and sheep red blood cell (SRBC) test, respectively.

Results: As compared to control, combination groups of GC+BAA1 and 2 brought about a significant decrease in the mRNA expression of $\beta 2 A D R, C O X-2$, and cytokines $(P<0.05)$. The ovulation rate was reduced in all combination ratios $(P<0.05)$. A significant reduction was observed in the plasma estradiol content on GC+BAA groups $(P<0.05)$ and the content of progesterone and androgen were statistically similar in some of these groups. Although NLR was similar in GC+BAA2 and 3, these groups had more content in the whole immunoglobulin (Ig) and IgM ( $P<0.05)$. The results indicated that body weight and food consummation were decreased in all of the combination groups $(P<0.05)$.

Conclusion: The GC and BAA combination may result in a significant reduction in some of the boosting factors on ovarian cancer, like ovulation intensity, pro-inflammatory mediators, and some of the ovarian steroid hormones that could define as the therapeutic approaches for the chronic inflammation-based carcinomas like ovarian cancer.

\section{Background}

Ovarian cancer occurs only in the reproductive tissues of females. It is the fourth most common cause of cancer death among women, after lung, breast, and colorectal cancers and the most common cause of death from gynecological cancers in the western world and the lowest in Asia and Africa [1, 2]. Among the etiological factors of ovarian cancer like hereditary, reproductive, hormonal, and lifestyle agents, inflammationdepended factors including endometriosis, pelvic inflammatory disease and ovulation, have been cited as the risk factor in some studies [3]. The ovulation process accounts for the inflammation- depended event because it is characterized by the local production of pro-inflammatory mediators. These substances may affect the ovarian epithelial surface by creating and enhancing malignant cells development [4]. Besides, the immune system influences the ovulatory process with the infiltration of leukocytes and the production of inflammatory mediators such as cytokines, closely associated with involved ovulatory components [5].

In vivo animal models of ovarian cancer create the opportunity to evaluate the steps of carcinogenesis from the beginning of progression to latestage metastatic disease. Such these researches about the etiology of ovarian cancer have been limited by the lack of suitable spontaneous animal models [6]. Because unlike women, epithelial ovarian cancers (EOC) is seldom observed in most wild or domestic mammals may be due to normal pregnancy, breastfeeding, or seasonal reproduction; for this reason, the domestic egg-laying hens (Gallus domesticus) is a unique and primary animal model that is similar to women in histopathological traits [7].

During 2 last decades, laying hen has been as an experimental animal in the anti-inflammatory strategies- related-studies like, sources of omega-3 fatty acids [8], Non-steroidal anti-inflammatory drugs (NSAIDs) [9], herbal elements [10], that are reported to reduce the severity of ovarian cancer. Therefore, the presentation and evaluation of different anti-inflammatory strategies may influence the improvement of ovarian cancers' carcinogenic traits. Among these, some pharmaceutical methods of inflammation -depended respiratory disorders like asthma and chronic obstructive pulmonary disease (COPD) can candidate in prevention and treatment of inflammatory aspects of ovarian cancer. Separate usage of beta-2 adrenergic agonists (BAA) and glucocorticoids (GC) is current to attenuate inflammatory signs of respiratory disorders [11, 12]. Nevertheless, it has been reported that the chronic activation of these receptors, either beta-2 adrenergic receptor ( $\beta 2 A D R$ ) or glucocorticoid receptor induced by prolonged treatment of their agonists, could cause the desensitization and down-regulation of these receptors [13, 14]. However, it has been proven that combination therapy of these agonists not only attenuates desensitization and down-regulation both $\beta 2 A D R$ and glucocorticoid receptors but also synergistically enhances the efficiency of anti-inflammatory related pathways of these agonists in immune cells and lung tissue $[13,15]$.

Given the content explained above about existing restrictions on glucocorticoid and beta-2 adrenergic pathways when their agonists exert alone, practical strategies for maintenance of the receptor efficiency is required. For this reason, we suppose that the combination of BAA and GC may be evaluated as a solution to prevent the desensitization and down-regulation of $\beta 2 A D R$ in cancer cells.

Page $2 / 20$ 


\section{Results}

\section{mRNA expression of pro- and anti-inflammatory mediators and $\beta 2 A D R$}

The relative abundances of $\beta 2 A D R$ and cyclooxygenases 1 and 2 (COX-1 and COX-2) mRNA and the cytokines of interleukin (IL)-1 $\beta$, IL-6, IL-10, and tumor necrosis factor-a (TNF-a) mRNA in the Pre-ovulatory follicles (F1) normalized to $\beta$-actin as a housekeeping gene, were shown in Figs. 1 and 2 , respectively.

According to Fig.1.A, B2ADR mRNA expression was significantly higher in the combination group GC+ BAA3 and significantly less in others compared to the control $(P<0.01)$. However, rather than BAA and GC groups, $\beta 2 A D R$ mRNA expression was significantly higher in all of the combination groups GC+ BAA1, 2 and $3(P<0.01)$.

COX-1 and COX-2 mRNA expressions in Follicle F1 of hens were indicated in Fig1 B, C. Compare to control, there were the significant decrease in COX-1 mRNA expression in BAA, GC, BB, and GC + BAA2 groups and the significant increase in the combination groups of the GC+ BAA1,3 (P< 0.01). Nevertheless, COX-1 mRNA expression was significantly higher in all of combination groups than $B A A$ and $G C$ groups $(P<0.01)$. Compared to control, COX-2 mRNA expression was down-regulated in BAA, BB, and GC + BAA1, 2 groups $(P<0.01)$, up-regulated in GC ( $<<0.01)$ and not affected in $\mathrm{GC}+\mathrm{BAA} 3(\mathrm{P}=0.07)$. In contrast, all of combination groups had significantly the less COX-2 mRNA expression ( $<<0.01)$ than the GC group and significantly the higher expression than the BAA and BB groups $(P<0.01)$.

IL-1 $\beta, I L-6, I L-10$, and TNF-a mRNA expressions in Follicle F1 of hens were indicated in Fig. 2 A-D. Despite significantly down-regulating IL-1 $\beta$ in all treated hens compare to control $(P<0.01)$, all of the combination groups had a higher relative abundance of IL-1 $\beta$ mRNA than BAA and GC groups $(P<0.01)$. Except GC + BAA3 group, other treated groups had less TNF-a, IL-6, and IL-10 mRNA expression than the control ( $<<0.01)$. However, BAA and GC groups had the less levels of TNF-a, IL-6, and IL-10 mRNA expressions than GC + BAA1, 2, and 3 groups (P< 0.01$)$.

\section{ELISA analyses of plasma estradiol, progesterone, and androgen}

Changes in the estradiol, progesterone, and androgen (testosterone) contents in the plasma of control and treated laying hens have been presented in Fig. 3 A-C. Compare to control, the hens supplemented by BAA, had significantly a higher $(P<0.01)$ and the hens supplemented by GC and combination groups had the considerable lower plasma contents of estradiol $(P<0.01)$. Like Estradiol, BAA gave rise to elevate ( $<<0.01)$ and $G C$ resulted in a significant decline $(P<0.01)$ progesterone content of plasma as compared to control. However, the plasma content of progesterone was less, unaffected and higher in combination strategy of $G C$ and $B A A$ as compared to $B A A(P<0.01)$, control $(P=0.59)$, and $G C$ groups $(P<0.01)$ respectively. Compare to control, the BAA group significantly had more $(P \leq 0.05)$, combination group $G C+B A A 3$ significantly had less plasma content of testosterone $(P<0.05)$. However, the plasma content of this hormone was statistically similar $(P>0.05)$ in the other treatments, as compared to control.

\section{The function of cellular and humoral immunities}

Fig. 4 A-C has shown the changes of neutrophil (heterophile) and lymphocyte percentages, neutrophil (heterophile) and lymphocyte ratio (NLR), and the serum content of Immunoglobulins' (Ig) G, M, and whole Immunoglobulin content (SRBC) were shown in Fig.5. According Fig. 4 A, there was a significant increase in neutrophil percentage on GC and GC + BAA1 groups as compared to control and the other treated laying hens $(P<0.01)$ and BAA group significantly indicated the lowest neutrophil percentage among other groups. Lymphocyte percentage in the GC group was significantly $(P<0.05$, Fig. 4 B) lower than other experimental groups. The observed significant changes in neutrophil and lymphocyte percentages resulted in a significant increase of NLR in GC and GC + BAA1 groups (Fig.4 C, P<0.01) compare to other groups. The birds supplemented by GC Fluticasone, significantly had the lowest serum Immunoglobulin (Ig) G, IgM and consequently whole Ig density (P<0.05, Fig. 5 ) as Compared to control and the other treatments. Despite this fact that BAA group indicated the statistically similar serum IgG and whole Ig $(P=0.05$ and $P=0.086$ respectively, Fig. 5) than control, BB, GC + BAA2 and 3 showed the significant enhancement in whole Ig, and $M$ compare to control $(\mathrm{P}<0.05$, Fig. 5).

\section{Ovarian and body functions}

The changes in Hens' average body weight (BW) and food consummation as the criteria of body function have been presented in Fig. 6 and their ovulation rate (laying frequency) and follicle sizes F1 to F5 have been shown in table 3. According to Fig. 6, average BW was significantly reduced $(\mathrm{P}<0.05)$ in $\mathrm{GC}$ and combination groups as compared to the other experimental groups. However, there was no difference in average $B W$ between hens supplemented by GC and combination groups. Food consummation was significantly higher in the BAA group and less in the GC and all of combination group as compared to control $(P<0.05)$. The results showed in table 3 that a significant difference was seen between treated groups and control $(P<0.01)$ on ovulation rate, so that a significant increase was seen in $B A A(P<0.01)$ and $B B(P<0.05)$ groups and a significant reduction $(P<0.01)$ in $G C$ and combination groups. Hens' follicle size supplemented by $G C$ were significantly $(P<0.01)$ influenced much more than the other experimental groups, because of having the smallest diameter in GC follicle F1 among experimental groups and lack 
(not observed, N.O.) of follicles F2 to F5 in the GC group. Furthermore, any significant difference was seen in BAA, BB, and GC + BAA3 groups in follicle F1 compare to control, the combination groups GC + BAA1 and 2 gained significantly smaller follicle F1 than BAA (P<0.05) and control.

\section{Discussion}

Laying hen has been known as a robust model of spontaneous ovarian cancer in human due to the expression of some molecular markers, proinflammatory mediators, site of origin (oviduct and ovary), performed at relatively little cost and same presentation and progression to the human disease that appears to be associated with prolific ovulation and aging $[7,16]$. Moreover, similar to women ovarian cancer, there are comparatively more immune cells in laying hens' ovarian tumors than in normal ovaries, and the highest immune cell content occurs in serous tumors $[16,17]$.

In the majority number of evidence, the stimulation of beta-2 adrenergic signaling was mentioned to involve in multiple cellular processes that contribute to the initiation, progression, and metastasis, including inflammation $[18,19]$. Nonetheless, it has proven that in the tumor microenvironment, which is largely orchestrated by inflammatory cells [20], the beta-2 adrenergic transmembrane signaling is impaired and the number of $\beta 2 A D R$ reduces due to increasing the number of deficient receptors or cell types lacking receptors, in some cancer types [21]. Therefore, the GC and BAA combination could be as an efficient strategy to restore the transmembrane $\beta 2 A D R$ number and its cellular signaling. Therefore, this could be as the first report to demonstrate the effects of the synchronous supplementation of GC and BAA in the ovarian inflammatory cells on laying hen model of ovarian cancer.

\section{Ovarian mRNA expressions}

As shown in the Fig.1-A, compare to control, we observed the significant down-regulation of $\beta 2 A D R$ in Individual treatments of BAA, GC, BB and $\mathrm{GC}+\mathrm{BAA} 1,2$, and significant up-regulation in GC+BAA3 of $\beta 2 A D R$ mRNA expression. Nevertheless, in comparison with BAA and GC, all of the combination groups indicated a significant increase in $\beta 2 A D R$ mRNA expression that are in agreement with previous reports regarding increase in $\mathrm{mRNA}$ expression of this adrenergic receptor $[13,15]$.

Cellular density of $\beta 2 A D R$ derives the various factors like the type of tissue [22, 23], cellular age [24], inflammatory condition [23], and overstimulation of $\beta 2 A D R$ in the face of excessive BAA exposure [22]. Concerning the factors mentioned above, a decrease in $\beta 2 A D R$ mRNA expression could probably be as a consequence of $\beta 2 A D R$ overstimulation BAA Salmeterol (1 ppm BW) and prolonged agonist exposure (four weeks) in the hens' ovarian epithelial tissue within the inflammatory condition of ovulation. On the other hand, according to the results derived by the previous studies about the evaluation of BAA Salmeterol on membrane $\beta 2 A D R$ density $[25,26]$, it has been proven that the administration of BAA Salmeterol brings about a considerable stabilization of membrane $\beta 2 A D R$ because of having a very low efficacy for stimulating arrestin2 and G protein-coupled receptor kinase enzyme (GRK) phosphorylation as essential mediators to induce $\beta 2 A D R$ desensitization, downregulation and internalization. Improvement of membrane $\beta 2 A D R$ density could be as an effective factor to downward cellular synthesis and degradability turnover of $\beta 2 A D R$ proteins and consequently causes to decline its gene transcription. Despite this fact that GC gave rise to upregulate $\beta 2 A D R$ mRNA expression in some of the past researches, but the studies like Tan et al. 1997 reported high-dose inhaled GC Fluticasone did not up-regulate lymphocyte $\beta 2$-AR as compared with a single dose of oral prednisolone [27]. In this regard, similar to BAA Salmeterol, GC Fluticasone has been indicated to decrease in protein expression of arrestin-2 and GRK [28, 29] and as a result, causes to improve membrane B2ADR density and decline its cellular mRNA. Our results demonstrated that, compare with the other groups, the combination groups had the different behaviors, so that GC + BAA1 and 2 down-regulated and GC + $\beta B A A 3$ unregulated $\beta 2 A D R$ mRNA expression as compared to control; nevertheless, all of the combination groups enhanced this expression In comparison to BAA Salmeterol and GC Fluticasone that were in accordance with the some documents $[13,30]$. They mentioned BAA and GC combination may regulate $\beta 2 A D R$ function by increasing both of protein and mRNA expression of the receptor, restoring G-protein/ $\beta 2 A D R$ coupling, and inhibiting $\beta 2 A D R$ down-regulation given rise after exposure to high doses of BAA on respiratory disorders. Thus, it's supposed that compare to individual usage of BAA and GC, supplementing the hens with all of combination groups caused to up-regulate $\beta 2 A D R$ mRNA expression via the positive effect of GC on the mRNA expression of this receptor, as mentioned above. $\beta 2 A D R$ has been shown to play a considerable role in different ovarian events like ovulation, hormonal secretion, and puberty [31-33]. However, it has been reported that this receptor exhibited significant overexpression in tumor tissue on reproductive malignancies like ovarian cancer [34]; it has been recommended that beta blocker usage reduced the chance of death compared with that of non-users $[34,35]$. Anyway, on the one hand, according to this fact that reduction in egg-laying frequency (ovulation rate) results in a decrease in ovarian cancer [36, 37], on the other hand, hens treated by all of the combination groups had a much less ovulation rate than control, BAA (BAA elevated significantly compare to control) and BB (Table 3 ), it could reach to this opinion that increase in membrane density of $\beta 2 A D R$ possibly doesn't boost the beginning and severity of ovarian cancer in laying hens as the model of women's ovarian cancer. This opinion was stood out when accompanied with the recent documents indicating that there are no associations between BB usage and cancer survival, prognosis, and mortality [38-40].

As the rate-limiting enzymes, cyclooxygenase-1 and 2 (COX) have the critical role in the various physiological roles, and be involved in different ovarian reproduction processes like ovulation [41]. Although, COX-1 has been known to be expressed in most cells and tissues and remains in 
constant expression under most physiologic conditions, COX-2 is inducible and generally only expressed in response to various inflammatory reactions [42]. However, both of COX-1 and 2 have been reported to be up-regulated throughout the ovarian carcinoma [16]. Here, we reported that the supplementation of BAA Salmeterol and BB propranolol down-regulated both COX-1 and 2, and GC Fluticasone resulted in the significant up-regulation of COX-2 and down-regulation COX-1. According to Shore's study, TNF-a and IL-1 $\beta$ synergistically perform to promote $\beta 2 A D R$ desensitization through the induction of COX-2 expression [43]. Therefore it's believed that the down-regulated TNF- $\alpha$ and IL-1 $\beta$ derived by the supplementation of BAA Salmeterol (Figure 2, A and D) caused not only to down-regulate COX-2 expression but also lead to a decrease in B2ADR desensitization. Our COX-1 result was in agreement with some reports that have demonstrated that glucocorticoids down-regulate COX-1 gene expression [44]; nonetheless, dislike our COX-2 result, several documents indicated that COX-2 expression is inhibited by glucocorticoids $[45,46]$. However, some studies reported that glucocorticoid therapy enhances COX-2 expression. In this regard, Sun et al. 2008 indicated that GC induced COX-2 gene expression via inducing the interaction of glucocorticoid receptor with C/EBP- $\beta$ (CCAAT/enhancer-binding protein- $\beta$ ) and activation of p38 MAPK (mitogen-activated protein kinase) in cardiomyocytes; in fact, activation of glucocorticoids and their receptor were necessary for COX-2 gene expression due to the binding of both glucocorticoid receptor and C/EBP- $\beta$ to COX-2 promoter [47]. Although, all of the combination groups didn't have the more anti-inflammatory efficiency for down-regulating COX-2 mRNA expression than BAA group, GC + BAA1 and 2 had the less COX-2 mRNA density compare to the control and GC group. However, except for the effect of GC + BAA2 on COX-1 compare to control, the other combination groups up-regulated COX-1 mRNA expression as compared to control, BAA, GC, and BB groups. Therefore, according to decreasing COX-2 observed from combination groups, some of these groups are possibly capable of having the anti-inflammatory role via down-regulating COX-2.

Cytokines as products of immune system have also been proven to be synthesized by an extensive range of non-immune cells, like the normal ovarian cells; and their action in the ovary has been described as the motivational processes of follicular development, activation of leukocytes required for ovulation, and tissue remodeling during ovulation [48]. Meanwhile, cytokines are reported to associate with ovarian cancer via regulating growth, signaling, and differentiation of both tumor and stromal cells and may affect on behavioral traits of malignant cells [49]. Among these, TNF-a, IL-1 $\beta$ and IL-6 [49] as the pro-inflammatory cytokines, and IL-10 as an anti-inflammatory cytokine [50] have been shown respectively to promote and restrict ovarian tumor genesis, growth, and progression. According to the diagrams indicated in Fig. 2 , except IL-1 $\beta$, the other mentioned cytokines showed the similar changes in of mRNA expression when compared to control; so that, all of the treatments either individuals or combination groups have shown the less IL-1 $\beta$ mRNA expression than control; while, GC + BAA3 group had the highest mRNA expression of TNF-a, IL-10, and IL-6 among the others. However, in all of the mentioned cytokines, the individual groups of BAA, GC and BB had the lowest mRNA expression when compared to control and combination groups. Despite this fact that some studies reported that other BAAs led to a significant increase in mRNA and protein expressions of three cytokines TNF-a, IL-1 $\beta$, and IL-6 [51, 52], Salmeterol has been known to inhibit the secretion of these cytokines. In this regard, Hu et al. showed that Salmeterol inhibits the activation of MAPK and nuclear factor kappa-light-chain-enhancer of activated B cells (NF- $₫$ B) [53] as main pathways of induction of some pro-inflammatory cytokines including IL-1 $\beta$, IL-6 and TNF-a [54]. Anyway, the lower mRNA expression of IL-10 in the BAA group was in contrast to the previous studies that have worked not only on Salmeterol $[55,56]$ but also on the other BAAs [57]. Similar to BAA, our results agreed with other researches having documented that GC markedly suppressed mRNA expression of key pro-inflammatory mediators including TNF-a, IL-1 $\beta$, and IL-6 [58, 59], and was unlike to others that had mentioned GCs may regulate inflammatory action by increasing IL-10 mRNA expression as well as higher serum IL-10 concentration [60]. Although having the higher mRNA expressions of mentioned cytokines than individual groups, some combination groups down-regulated the cytokines mRNA expression compare to control. In agreement with our results, some researches have proven that the combination of these drugs induce a significant decrease of IL-1 $\beta$, IL-6, and TNF-a [61, 62]. In this regard, Fragaki et al. 2006 suggested that combination of Salmeterol and Fluticasone is capable of decreasing pro-inflammatory cytokines by reducing to reduce the NF- $\mathrm{B}$ and Activator protein 1 (AP-1) activity via 1) the reduced activation of extracellular signal-regulated kinase (ERK)1/ERK2 and c-Jun N-terminal kinases (JNKs) pathway and 2) the reduced

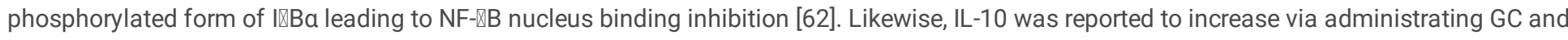
BAA more effective than the sole administration of the GC [63] that in our results was just similar to GC + BAA3 group as compared to control; nevertheless, all of the combination groups had the higher mRNA expression of IL-10 than the individual groups.

\section{The function of ovarian hormones}

As major reproductive steroid hormones, estradiol, progesterone, and testosterone (androgen) have been confirmed to play the functional roles to regulate growth, differentiation, and function of an extensive range of target tissues in the females' reproductive system [64]. It has been reported that there is an association between ovarian cancer and ovarian hormones [65]; on the one hand, Estrogen was shown to regulate growth and differentiation in the normal ovaries and has mutagenic effects. Beside, some evidence confirmed that estrogen accelerates the inflammatory process through the up-regulation of cytokines including IL-1 $\beta$, IL-6, TNF-a and matrix metalloproteases (MMPs) [66].

Progesterone, on the other hand, has been indicated to induce apoptosis and reduce cell membrane permeability that gives rise to decrease invasive potential [67]. This storied hormone has been reported to have a protective role in preventing inflammation during pregnancy by reducing of IL-6 and TNF-a, and by the recovery of antioxidant enzyme performance in some tissues [68]. Likewise, Emerging evidence has mentioned that androgen-depended pathways have also been known to plays an important role in the pathogenesis and progression of malignancies, prostate, breast, and ovarian cancers $[69,70]$. More interesting that androgen therapy offsets the inflammatory process and 
reduces the intensity of disease by mechanisms inhibiting inflammatory cytokines expression and function like TNF-a, IL-1 $\beta$, and IL- 6 [71]. About the results expressed in Fig. $3 \mathrm{~A}-\mathrm{C}$, the birds supplemented by BAA and BB, had significantly higher serum estradiol content that was in contrast to the GC and combination groups showing the lower estradiol content, as compared to control. Similar to our results in estradiol, serum progesterone content was the highest and lowest in the BAA and GC groups, respectively and all of the combination groups and BB statistically showed similar serum progesterone content compare to control. Except for BAA and GC+BAA3 groups, the other treatments also indicated the same behavior on the serum androgen. In keeping with our results, the previous evidence reported that catecholamines elevated serum estradiol, progesterone, and androgen concentrations in the experimental animals [72-74]. This up-regulation has been mentioned that not only has directly been derived by theca layer stimulation of the ovarian follicles [72] but also has been influenced via indirect regulation of the pituitary gonadotropes response to $\mathrm{GnRH}$ [75] that these routes are activated through current beta-2 adrenergic signaling of formation of cAMP. According to the obtained finding of previous studies, reduced content of serum estradiol and progesterone observed on the GC group in our study could be derived by the factors like inhibition of hypothalamus- Pituitary - gonads [76], inhibition of estradiol activity by increasing the expression sulfotransferase [77], and decreasing luteinizing hormone (LH) receptor number [78]. Because the administration of BAA+ GC has been defined as an anti-inflammatory strategy in respiratory disorders, the valid evidence was not found to document ovarian steroids hormones change in experimental animals' plasma treated by combination strategy of BAA and GC. For this reason, the presentation of our results about plasma ovarian hormones changes could be defined as the first report that mentions the effect of combination groups on these hormones.

\section{The function of cellular and humoral immunities}

Because of incessant ovulation and chronic inflammation, the immune system is assumed to be defined as the main mediator of ovarian cancer [79]. In this regard, the increasing documents are indicating that systemic inflammatory activation derived by cancer cells anticipates tumor progression via inducing cancer proliferation and metastasis or promoting angiogenesis [80, 81]. Therefore, the inflammatory markers, like the neutrophil (called as heterophile in the birds)-lymphocyte ratio (NLR) has been mentioned as a considerable index of the systemic inflammatory response for predicting the prognosis of different cancers like ovarian cancer [81]. Generally, the factors that increase ovarian cancer risk were accompanied to higher NLR, and factors decreasing risk were associated lower NLR [82]. The elevation of NLR derived ovarian cancer, is created via increasing circulating neutrophils and decreasing lymphocytes counts. Our results showed in Fig. 5 (A-C) that the administration of GC Fluticasone gave rise to significantly boost neutrophil and NLR and decrease in lymphocyte as compared to control and BAA groups. In agreement with our results, some of documents have reported that on the one hand, GC not only causes to elevate the accumulation and survival of neutrophils [83] but also to up-regulate of anti-apoptotic Bcl-2 (B-cell lymphoma- 2) family members, activate NF-kB, Suppress components of the extrinsic pathway of apoptosis, and induce signaling molecules such as MAPK phosphatase-1 (MKP-1) and Serum and glucocorticoid activated kinase-1 (SGK-1) [84] that promote inflammatory aspects in neutrophils. On the other hand, GCs indicated the different behavior on lymphocyte numbers rather than neutrophil because GC results in the skew of T cells, activation of NF-kB via stimulation of Toll-like receptors [85], and activation of death-inducing genes and consequently induce apoptosis [86]. Observed increase and decrease in neutrophils and lymphocyte respectively resulted in a rise of NLR in hens administrated by GC Fluticasone that was similar to the some studies showing that treatments using GC had higher NLR values that are mainly derived by higher neutrophil counts [87]. Despite being none significant as compared to control, the BAA group had the lowest neutrophil percentage and NLR among other treatments and except to GC, BAA had the same effect on lymphocyte percentage with the other treatments. In this regard, some documents have proved that activation of the $\beta 2 A D R$ inhibits inflammatory responses in neutrophils via the various intra-cellular pathways like clearance of cytosolic $\mathrm{Ca}^{2+}$ and inhibition of the generation of superoxide anion $\left(02\left(\left(^{-}\right)\right)\right.$production $[88,89]$ and release of acetylcholine that exerts its anti-inflammatory effects binding to alpha-7 nicotinic receptors [90]. Reduced neutrophil percentage observed in the BAA group could give rise to a significant reduction in NLR compare to GC and GC + BAA1. The nearest to these results, some studies have expressed that NLR could be the independent and straightforward predictor for inflammation-induced-respiratory disorders like asthma and COPD [91] that are improved by BAA [12] and combination of GC and BAA [15]. Despite having a significant increase in GC + BAA1, neutrophil percentage was statistically similar on GC + BAA2 and 3 as compared to control. Although having more neutrophils count than the BAA group, all of the combination groups indicated the anti-inflammatory effect due to having less neutrophil count compare to the GC group. In keeping with our results, some researches announced a reduction in neutrophils percentage for the patients administrated by Salmeterol plus Fluticasone propionate in the inflammation related respiratory disorders [92]. As result of the decrease in neutrophils percentage in combination groups, NLR was reduced in these groups as compared to the GC group; however, except for GC + BAA1, GC + BAA2, and 3 statistically had the similar influence on NLR compare to BAA, BB and control.

As easily extracted from serum via minimally invasive blood collection, autoantibodies or natural antibodies have become of particular interest as cancer biomarkers for current decades [93]. They have been confirmed to show the elevated concentration in very early cancer stages and during the transition to malignancy [94] and have been proven in patients with several carcinomas like ovarian cancer [95]. According to the main autoantibodies, IgG and IgM subclasses have been known to perform as the most and milder sensitive immunological responses respectively concerning protein-specific glycosylation profiles in serum of EOC patients as compared to healthy individuals [96]. Moreover, there are different documents regarding IgG and IgM effects on the growth of tumor cells. While Staff et al. 2012 mentioned that IgM might have an anti-tumor role in addition to IgG [97], Manjula et al. 1992 observed an Elevated level of serum IgG or IgM antibodies is in patients with cancers of epithelial origin, like breast, colon, and liver cancers [98]. However, Qiu et al. 2003 achieved to this fact that tumor-derived IgG was involved at 
least, in part, in the survival and growth of epithelial tumor cells because anti-human IgG induced apoptosis and growth inhibition of cancer cells in vitro and in vivo [99]. According to the results shown in Fig. 5, the birds administrated by GC had the least whole Ig, IgG, and IgM among other groups that were in agreement with evidence proved that corticosteroids appear to have a negative correlation on levels of some serum immunoglobulins [100]. Regarding this effect, GC has been reported to decrease B cells through promoting intracellular pathways of apoptosis and death-inducing genes [86], modulating peripheral B cell maturity via inhibiting activation-induced cytidine deaminase (AICDA) expression [101], dephosphorylation of ERK-1/2 via increased dual-specificity protein phosphatase1 (DUSP1) expression [102], and down-regulating Bruton Tyrosine Kinase (BTK) for B-cell activation [103]. Except for a significant enhancement of IgM, it was not observed the considerable difference in whole Ig and IgG in the BAA group compare to the control. Nevertheless, it is supposed that the comparative advantage of Ig production in some of the combination groups could be derived by enhancing of beta-2 adrenergic signaling- mediated pathways in these groups due to more beta-2 adrenergic receptor in B- cell membrane; so that Sanders 2012 mentioned activation of two pathways, namely LynCD19-Akt-NF-kB p50-p65 and PLCY0032a-PKC-p65 having the role of an increase in the amount of IgG1 secreted per B cell, were found to converge by CREB that is emerged by beta-2 adrenergic signaling- mediated pathways [104]. In contrast to our thinking, Lee et al. 2016 reported a significant down-regulation for both $B$ cell proliferation and IgG expression (both mRNA and protein) using Fluticasone : Salmeterol combination with 1:10 ratio and Fluticasone alone [102].

\section{Ovarian and body functions}

Ovulation is defined the major contributor to emerge ovarian cancer that was supported by two hypotheses of incessant ovulation (Fathalla's incessant ovulation hypothesis) and inflammation [37]. Fathalla has been theorized the continuous involvement of the ovarian surface in the process of ovulation because of repeated processes of rupture and repairing the wound of the ovarian surface. Over time, these processes boost the possibility of errors occurring during DNA replication. On the other hand, according to the inflammation hypothesis, the ovulation-related events have been reported to resemble an inflammatory reaction that accompany with leukocytes infiltration and production of inflammatory mediators like cytokines, Vascular growth factors (VEGF), Prostaglandins, and intracellular signaling pathways closely associated with inflammatory reaction [105]. Concerning these hypotheses, it is supposed that the inhibition of ovarian cancer will occur if the process of ovulation is modified by suppressing inflammatory mediators and signals. Regarding the results presented in Table 3 , the laying hens supplemented by BAA Salmeterol significantly showed a more ovulation rate and being in contrast with GC and combination groups that had a lower egg-laying frequency as compared to control. Moreover, the GC group showed the smallest pre-ovulatory follicle (F1) size among the other groups, insofar as, the follicles of F2 to F5 were not observed (N.O.) in the GC group. However, BAA, BB, and GC+ BAA 3 statistically indicated the similar follicle size F1 and except GC, all of the treatments had a similar size at follicles F2 to F5 compare to the control. In addition to the influence of inflammatory events, the factors like nutritional and metabolic factors and relating hormones of the hypothalamus-pituitary-ovary axis have been documented to play the fundamental roles in the function of ovulation and follicular development and differentiation. About the effect of nutrition and metabolic status, some evidence demonstrated energy balance, nutrients (fatty acids, glucose, and amino acids), and metabolic hormones like insulin, IGF-I and growth hormone implicate in ovarian functions such as the follicular development and ovulation [106]. GnRH, gonadotropins, and ovarian hormones, on the other hand, have been reported to preliminary effects on follicular development and ovulation [107].

According to our gained results on mRNA expression of ovarian inflammatory mediators and ovarian hormones, and nutrition and metabolic status explained above, it could reach to this belief that each treatment influenced on ovulation rate and follicular size by the effect on the situation of ovarian hormones and metabolic status. Regarding the results shown in Fig. 6, food consummation was elevated in the BAA group and decreased in GC and combination groups that were in agreement with previous study [108] in the GC group. Enhancement of food intake observed in the BAA group gave rise not only to improve live BW that represents positive energy balance but also to be as one of the confirmed reasons [106] for increasing ovulation rate and follicular development. Moreover, BAA was shown to increase insulin and IGF-I [109, 110] and growth hormone [111] that promote ovulation and follicular growth. Enhanced follicular growth and ovulation rate could also be as the results of elevated serum estradiol and progesterone in the birds administrated by BAA Salmeterol. As one of the contributing factors of ovulation, inflammatory mediators that their mRNA expressions were down-regulated in the BAA Group, do not seem to have enough influence on ovulation and follicular growth in this group compare to ovarian hormones and metabolic status. Reduced ovulation rate and follicular growth observed in the GC group could be derived by: 1) Decrease in food intake that resulted in negative energy balance and consequently loss of live BW observed in the GC group, 2) induction of Insulin resistance [112], disturbance of IGF-I [113] and down-regulation of growth hormone [114], 3) observed down-regulation of estradiol and progesterone, and 4) observed reduction in mRNA expression of inflammatory mediators. Despite indicating the statistically similar size at the most classes of follicular growth, like the GC group, combinations groups had lower ovulation rate than the control, BAA, and BB . In this regard, authors believe that BAA and GC could have the dominant and synergic actions on some effective factors on ovulation intensity and follicular growth. BAA is supposed to suppress the inhibiting role of GC on some of the reproductive hormones and metabolic mediators like insulin, IGFs and growth hormone; while as the synergic effect, BAA promotes GC effect on the decrease in inflammatory mediators and finally this BAA and GC interaction gives rise to improve the follicular size and decrease in ovulation rate in combination groups. 


\section{Conclusion}

The results of this study have indicated that the administration of individual and combination therapy of glucocorticoid (GC) Fluticasone and beta-2 adrenergic agonist (BAA) Salmeterol, and beta blocker (BB) propranolol brought about a down-regulation in mRNA expression of the most pro-inflammatory mediators. Despite the elevation of neutrophil lymphocyte ratio in GC group, the content of serum immunoglobulin and some of the ovarian hormones were the least in this group and improved in BAA, BB, and some of the combination groups. However, the ovulation rate was lower in GC and combination groups and higher in BAA and BB groups. Taken together, the combination strategy of these agonists improved some ovarian cancer-related inflammatory characters more than individual treatments. To our knowledge, this study provided the first report to evaluate BAA and GC combination in laying hens as a spontaneous pre-clinical model of human ovarian cancer, could usher in new insight into the potential mechanisms of stabilization of membrane $\beta 2 A D R$ in the reduction of several carcinomas like ovarian cancer, and will establish the foundation for clinical experiments to evaluate the pro- and anti-carcinogenic factors for the prevention and suppression of ovarian cancer in women.

\section{Materials And Methods}

\section{Animal care}

One hundred twelve 92-week-old commercial strains of White Leghorn laying hens (Gallus domesticus) were housed at the poultry research farm of the department of animal sciences, University of Tehran at Karaj. Laying hen husbandry was adjusted and approved by the institutional animal care of this institute. The birds were exposed to a photoperiod of $16 \mathrm{~h} \mathrm{light:} 8 \mathrm{~h}$ dark with lights on at 06:00 and lights off at 22:00 with food and water provided ad libitum. Laying frequency (ovulation rate), feed intake, and mortality were monitored and recorded daily and were reported as body function. The value and ingredients of the test diet was indicated in Table 1.

All laying hens were randomly divided and orally supplemented into seven groups ( $n=16)$ included: control, BAA Salmeterol (1 ppm body weight, BW), GC Fluticasone (2 ppm BW), 3 ratios of Fluticasone: Salmeterol ratio (2:0.5 ppm BW, 4:1 GC+BAA1; 2:1 ppm BW, 2:1 GC+BAA2; and 2:2 ppm BW, 1:1 GC+BAA3) and beta blocker (BB) Propranolol (2 ppm BW) for four weeks.

\section{Blood collection and tissue samples}

For evaluating and cellular and humoral immunities, and ovarian hormones responses, blood samples $(5 \mathrm{ml} / \mathrm{hen})$ were randomly collected from the brachial vein from 8 laying hens per group at the end of four weeks and their serum and plasma were centrifuged (at $3000 \times$ rpm for $15 \mathrm{~min}$ ) and stored at $-20^{\circ} \mathrm{C}$ for determination of humoral immune and ovarian hormones respectively.

\section{Immune responses}

Blood samples were smeared on to a glass slide to calculate of the neutrophil (heterophil)-lymphocyte ratio (NLR) as a criterion of cellular immunity. After drying, the smears were stained with May-Grünwald- Giemsa stain [115]. The NLR was calculated by dividing the number of neutrophils by the number of lymphocytes. For measuring humoral immunity, on the $14^{\text {th }}$ and $20^{\text {th }}$ day of the experiment, all of hens were injected with $0.1 \mathrm{~mL}$ of $0.25 \%$ suspension of sheep erythrocytes (SRBC, provided from a healthy male sheep) in phosphate buffer saline. AntiSRBC antibody titers of Hens' serum were obtained by the micro hemagglutination technique from samples taken from blood collection at the end of the experiment. Anti-SRBC titers were measured and reported as log2 of the last dilution's reciprocal after the whole agglutination [116].

\section{Ovarian hormones measurement}

The levels of plasma hormones of estradiol, progesterone, and testosterone were determined in this study by ELISA kits (Monobind® Inc, USA), given the mentioned manufacturers' recommendations. The sensitivity of detection, intra-, and inter-assay coefficients of variation (\%) for estradiol were

$6.5 \mathrm{pg} / \mathrm{ml}, 6.3 \%$, and $8.5 \%$, for progesterone were

$0.105 \mathrm{ng} / \mathrm{ml}, 1.5 \%$ and below $13 \%$ and for testosterone were

$0.038 \mathrm{ng} / \mathrm{ml}, 4.9 \%$, and $4.6 \%$, respectively.

\section{Tissue sampling}

After four weeks, 10 Hens per experimental group were euthanized by $\mathrm{CO} 2$ asphyxiation and necropsied. In this step, ovaries were removed and their yellow follicles were arranged base on their diameter (from F1 as pre-ovulatory follicles to $f 5$ as $5^{\text {th }}$ small yellow follicle) measured from follicle stigma. After measuring follicle size, Pre-ovulatory follicles $(12-35 \mathrm{~mm})$ were removed from ovaries, washed by saline kept at microtube, and stored at $-80^{\circ} \mathrm{C}$ for RNA isolation.

\section{RNA isolation and CDNA synthesis}


Total cellular RNA was isolated from frozen tissues using Trizol reagent (RNX-plus, Cinagen Co., Tehran, Iran) according to the manufacturers' recommendations. The quantity and quality of total RNA were determined by spectrometry and denaturing agarose gel electrophoresis, respectively. For RNA purification, samples were treated with DNase I (YT 9054, Yekta Tajhiz Azma co., Tehran, Iran) before reverse transcription reaction. cDNA was synthesized by the cDNA Reverse Transcription Kit (YT4500, Yekta Tajhiz Azma co., Tehran, Iran). The obtained CDNA was stored at $-80^{\circ} \mathrm{C}$ for analyzing gene expression using real-time PCR [41].

\section{Real-time PCR}

Target gene mRNA levels were measured using SYBR Green qPCR master mix (YT 2550, Yekta Tajhiz Azma co., Tehran, Iran) and a real-time rotary analyzer (Rotor-Gene 3000, Corbet Research, USA). Hen specific primers were gathered in Table 2 . The $\beta$-actin was used as a housekeeping gene to normalize target gene expression. Amplification conditions: $95^{\circ} \mathrm{C}$ for $300 \mathrm{~s}$ followed by 50 cycles of $95^{\circ} \mathrm{C}$ for $10 \mathrm{~s}$ and $60{ }^{\circ} \mathrm{C}$ for $30 \mathrm{~s}$ with melt curve measured at $65^{\circ} \mathrm{C}$ to $95^{\circ} \mathrm{C}$ every $0.5^{\circ} \mathrm{C}$ gradient for $5 \mathrm{~s}$. Control reactions lacking template were run for each target gene. Reactions were $10 \mu \mathrm{l}$ in total volume and $200 \mathrm{nM}$ of each primer.

\section{Statistical analysis}

According to general linear model (GLM), data were analyzed and compared by Duncan multiple range test using SPSS software (IBM SPSS Statistics, version 26.0, 2019). Statistical significance of each parameter was considered as significant at $P \leq 0.05$.

\section{Abbreviations}

GC: Glucocorticoid (Fluticasone); BAA: Beta-2 Adrenergic Agonist (Salmeterol); GC+BAA1: Fluticasone: Salmeterol ratio (2:0.5 ppm BW, 4:1); GC+BAA2: Fluticasone: Salmeterol ratio (2:1 ppm BW, 2:1); GC+BAA3: Fluticasone: Salmeterol ratio (2:1 ppm BW, 1:1); BB: Beta Blocker (Propranolol); B2ADR: Beta-2 Adrenergic Receptor; COX: Cyclooxygenases; ELISA: Enzyme-Linked Immune Sorbent Assays; NLR: Neutrophil (Hetrophil) to Lymphocyte Ratio; SRBC: Sheep Red Blood Cell; Ig: Immunoglobulin; EOC: Epithelial Ovarian Cancers; NSAIDs: Non-steroidal AntiInflammatory Drug; COPD: Chronic Obstructive Pulmonary Disease; ppm: Parts Per Million; BW: Body Weight; F1: Pre-ovulatory follicles; GLM: General Linear Model; N.O.: Not Observed; GRK: G protein-coupled Receptor Kinase enzyme; TNF-a: Tumor Necrosis Factor; IL: Interleukin; MMP: Matrix Metallo Proteases; LH: Luteinizing Hormone;

\section{Declarations}

\section{Ethics approval and consent to participate}

This study was approved by the Ethics Committee of University of Tehran.

\section{Consent for publication}

Not applicable.

\section{Availability of data and materials}

The data used or analyzed are all included in this published article.

\section{Competing interests}

The authors declare that they have no competing interests.

\section{Funding}

This study was done as Ph.D. Thesis, under grant number of 5803837 in the office of the Research Affairs, University of Tehran.

\section{Authors' contributions}

$\mathrm{AH}$ : study design, execution, analysis, and final approval of the manuscript; AZS, ZAP, AMA, and FP: study supervision; RM and MPA: laboratory assistance and data collection. All authors read and approved the final manuscript.

\section{Acknowledgements}

The authors thank the poultry research farm and laboratory staff in University of Tehran and Sari agricultural sciences and Natural Resources University for technical assistance. We appreciate Salman Nasrollahi and Seyed Mohammad Taghi Gharib Zahedi for their kind help during the course of study. 


\section{References}

1. Holschneider $\mathrm{CH}$, Berek JS. Ovarian cancer: Epidemiology, biology, and prognostic factors. Semin Surg Oncol. 2000;19(1):3-10.

2. Parkin DM, Bray F, Ferlay J, Pisani P. Global Cancer Statistics, 2002. CA Cancer J Clin. 2005;55(2):74-108.

3. Bast RC, Jr., Hennessy B, Mills GB. The biology of ovarian cancer: new opportunities for translation. Nat Rev Cancer. 2009;9(6):415-28.

4. Espey LL. Current status of the hypothesis that mammalian ovulation is comparable to an inflammatory reaction. Biol Reprod. 1994;50(2):233-8.

5. Bonello N, McKie K, Jasper M, Andrew L, Ross N, Braybon E, et al. Inhibition of nitric oxide: effects on interleukin-I $\beta$-enhanced ovulation rate, steroid hormones, and ovarian leukocyte distribution at ovulation in the rat. Biol Reprod. 1996;54(2):436-45.

6. Hales KH, Speckman SC, Kurrey NK, Hales DB. Uncovering molecular events associated with the chemosuppressive effects of flaxseed: a microarray analysis of the laying hen model of ovarian cancer. BMC Genom. 2014;15(1):709.

7. Johnson PA, Giles JR. The hen as a model of ovarian cancer. Nat Rev Cancer. 2013;13(6):432-6.

8. Pal P, Hales, K, Petrik J, Hales DB. Pro-apoptotic and anti-angiogenic actions of 2-methoxyestradiol and docosahexaenoic acid, the biologically derived active compounds from flaxseed diet, in preventing ovarian cancer. J Ovarian Res. 2019 Dec 1;12(1):49.

9. Urick ME, Giles JR, Johnson PA. Dietary aspirin decreases the stage of ovarian cancer in the hen. Gynecol Oncol. 2009;112(1):166-70.

10. Barua A, Bradaric MJ, Bitterman P, Abramowicz JS, Sharma S, Basu S, et al. Dietary supplementation of ashwagandha (withania somnifera, dunal) enhances nk cell function in ovarian tumors in the laying hen model of spontaneous ovarian cancer. Am J Reprod Immunol. 2013;70(6):538-50.

11. Zeiger RS, Szefler SJ, Phillips BR, Schatz M, Martinez FD, Chinchilli VM, et al. Response profiles to fluticasone and montelukast in mild-tomoderate persistent childhood asthma. J Allergy Clin Immunol. 2006;117(1):45-52.

12. Sitkauskiene B, Sakalauskas R. The role of beta(2)-adrenergic receptors in inflammation and allergy. Curr Drug Targets Inflamm Allergy. 2005;4(2):157-62.

13. Adcock IM, Stevens DA, Barnes PJ. Interactions of glucocorticoids and beta 2-agonists. Eur Respir J. 1996;9(1):160-8.

14. Kobayashi Y, Mercado N, Miller-Larsson A, Barnes PJ, Ito K. Increased corticosteroid sensitivity by a long acting $\beta 2$ agonist formoterol via $\beta 2$ adrenoceptor independent protein phosphatase 2A activation. Pulm Pharmacol Ther. 2012;25(3):201-7.

15. Barnes PJ. Glucocorticosteroids: current and future directions. Br J Pharmacol. 2011;163(1):29-43.

16. Yu Y, Edassery SL, Barua A, Abramowicz JS, Bahr JM, Hellstrom I, Luborsky JL. The hen model of human ovarian cancer develops antimesothelin autoantibodies in response to mesothelin expressing tumors. J Ovarian Res. 2011;4(1):1-9.

17. Bradaric MJ, Penumatsa K, Barua A, Edassery SL, Yu Y, Abramowicz JS, et al. Immune cells in the normal ovary and spontaneous ovarian tumors in the laying hen (Gallus domesticus) model of human ovarian cancer. PloS one. 2013;8(9):e74147.

18. Cole SW, Sood AK. Molecular pathways: beta-adrenergic signaling in cancer. Clin Cancer Res. 2012;18(5):1201-6.

19. Nagaraja AS, Dorniak PL, Sadaoui NC, Kang Y, Lin T, Armaiz-Pena G, et al. Sustained adrenergic signaling leads to increased metastasis in ovarian cancer via increased PGE2 synthesis. Oncogene. 2016;35(18):2390-7.

20. Coussens LM, Werb Z. Inflammation and cancer. Nature. 2002;420(6917):860-7.

21. Pérez-Sayáns M, Somoza-Martín JM, Barros-Angueira F, Diz PG, Gándara Rey JM, García-García A. Beta-adrenergic receptors in cancer: therapeutic implications. Oncol Res. 2010;19(1):45-54.

22. Johnson M. Molecular mechanisms of beta(2)-adrenergic receptor function, response, and regulation. J Allergy Clin Immunol. 2006;117(1):18-24.

23. Albano GD, Zhao J, Etling EB, Park SY, Hu H, Trudeau JB, et al. IL-13 desensitizes $\beta 2$-adrenergic receptors in human airway epithelial cells through a 15-lipoxygenase/G protein receptor kinase 2 mechanism. J Allergy Clin Immunol. 2015;135(5):1144-53.e539.

24. O'Hara N, Daul AE, Fesel R, Siekmann U, Brodde OE. Different mechanisms underlying reduced $\beta 2$-adrenoceptor responsiveness in lymphocytes from neonates and old subjects. Mech Ageing Dev. 1985;31(2):115-22.

25. Moore RH, Millman EE, Godines V, Hanania NA, Tran TM, Peng H, et al. Salmeterol stimulation dissociates beta2-adrenergic receptor phosphorylation and internalization. Am J Respir Cell Mol Biol. 2007;36(2):254-61.

26. Gimenez LE, Baameur F, Vayttaden SJ, Clark RB. Salmeterol efficacy and bias in the activation and kinase-mediated desensitization of $\beta 2-$ adrenergic receptors. Mol Pharmacol. 2015;87(6):954-64.

27. Tan KS, McFarlane LC, Lipworth BJ. Effects of oral and inhaled corticosteroid on lymphocyte beta2-adrenoceptor function in asthmatic patients. Br J Clin Pharmacol. 1997;44(6):565-8.

28. Chahal KK, Parle M, Abagyan R. Dexamethasone and Fludrocortisone inhibit hedgehog signaling in embryonic cells. ACS Omega. 2018;3(9):12019-25.

Page $10 / 20$ 
29. Pera T, Penn RB. Bronchoprotection and bronchorelaxation in asthma: New targets, and new ways to target the old ones. Pharmacol Ther. 2016;164:82-96.

30. Spahn JD. Combination inhaled glucocorticoid/long-acting beta-agonist safety: The long and winding road. Ann Allergy Asthma Immunol. 2018;121(4):428-33.

31. Aguado LI, petrovic SL, ojeda SR. Ovarian $\beta$-adrenergic receptors during the onset of puberty: characterization, distribution, and coupling to steroidogenic responses*. Endocrinology. 1982;110(4):1124-32.

32. Paredes AH, Salvetti NR, Diaz AE, Dallard BE, Ortega HH, Lara HE. Sympathetic nerve activity in normal and cystic follicles from isolated bovine ovary: local effect of beta-adrenergic stimulation on steroid secretion. Reprod Biol Endocrinol. 2011;9(1):66.

33. Ignatkov V, Pishulin AA, Markovich SI, Chushkova IS, Dobracheva AD, Pankov SS, et al. [Treatment of patients with disorders of the ovulatory function of central etiology with preparations affecting adrenergic mechanisms]. Akush Ginekol (Mosk). 1990(4):28-32.

34. Ramondetta LM, Hu W, Thaker PH, Urbauer D, Westin SN, Nagaraja AS, et al. No need to stress: Prospective clinical trial of adrenergic blockade during primary treatment in women with epithelial ovarian cancer. Gynecol Oncol. 2017;145:33-4.

35. Bunch KP, Annunziata CM. Are beta-blockers on the therapeutic horizon for ovarian cancer treatment?. Cancer. 2015;121(19):3380-3.

36. Landen Jr CN, Birrer MJ, Sood AK. Early events in the pathogenesis of epithelial ovarian cancer. J Clin Oncol. 2008;26(6):995-1005.

37. Fleming JS, Beaugié CR, Haviv I, Chenevix-Trench G, Tan OL. Incessant ovulation, inflammation and epithelial ovarian carcinogenesis: revisiting old hypotheses. Mol Cell Endocrinol. 2006;247(1-2):4-21.

38. Weberpals J, Jansen L, Haefeli WE, Hoffmeister M, Wolkewitz M, Herk-Sukel MPPv, et al. Pre- and post-diagnostic $\beta$-blocker use and lung cancer survival: A population-based cohort study. Sci Rep. 2017;7(1):2911-.

39. Jansen L, Weberpals J, Kuiper JG, Vissers PAJ, Wolkewitz M, Hoffmeister M, et al. Pre- and post-diagnostic beta-blocker use and prognosis after colorectal cancer: Results from a population-based study. Int J Cancer. 2017;141(1):62-71.

40. Brown C, Barron T, Bennett K, Sharp L. Associations between pre-and post-diagnostic use of beta-blockers and ovarian cancer survival. Eur J Cancer Care. 2015;24:21.

41. Hales DB, Zhuge Y, Lagman JAJ, Ansenberger K, Mahon C, Barua A, et al. Cyclooxygenases expression and distribution in the normal ovary and their role in ovarian cancer in the domestic hen (Gallus domesticus). Endocrine. 2008;33(3):235-44.

42. Eilati E, Pan L, Bahr JM, Hales DB. Age dependent increase in prostaglandin pathway coincides with onset of ovarian cancer in laying hens. Prostaglandins Leukot Essent Fatty Acids. 2012;87(6):177-84.

43. Shore SA. Cytokine regulation of $\beta$-adrenergic responses in airway smooth muscle. J Allergy Clin Immunol. 2002;110(6):S255-S60.

44. Łanocha-Arendarczyk N, Baranowska-Bosiacka I, Kot K, Gutowska I, Kolasa-Wołosiuk A, Chlubek D, et al. Expression and activity of COX-1 and COX-2 in acanthamoeba sp.-infected lungs according to the host immunological status. Int J Mol Sci. 2018;19(1):121.

45. Lim W, Park C, Shim MK, Lee YH, Lee YM, Lee Y. Glucocorticoids suppress hypoxia-induced COX-2 and hypoxia inducible factor-1a expression through the induction of glucocorticoid-induced leucine zipper. Br J Pharmacol. 2014;171(3):735-45.

46. Agrawal S, Guess AJ, Chanley MA, Smoyer WE. Albumin-induced podocyte injury and protection are associated with regulation of COX-2. Kidney Int. 2014;86(6):1150-60.

47. Sun H, Sheveleva E, Xu B, Inoue H, Bowden TG, Chen QM. Corticosteroids induce COX-2 expression in cardiomyocytes: role of glucocorticoid receptor and C/EBP-ß. Am J Physiol Cell Physiol. 2008;295(4):C915-C22.

48. Terranova PF, Rice VM. Review: cytokine involvement in ovarian processes. Am J Reprod Immunol. 1997;37(1):50-63.

49. Macciò A, Madeddu C. Inflammation and ovarian cancer. Cytokine. 2012;58(2):133-47.

50. Terlikowska K, Dobrzycka B, Terlikowski S. Ovarian cancer and inflammation. Part 2. Anti-inflammatory cytokines. Prog Health Sci. 2018;8(2):206-9.

51. Murray DR, Prabhu SD, Chandrasekar B. Chronic $\beta$-Adrenergic Stimulation Induces Myocardial Proinflammatory Cytokine Expression. Circulation. 2000;101(20):2338-41.

52. Lowden BM, Kulp AC, Saegesser J, Barnard D. Activation of Beta-adrenergic Receptors' Role in Formation of Enhanced Contextual Memory. Kent State University. 2018.

53. Hu Z, Chen R, Cai Z, Yu L, Fei Y, Weng L, et al. Salmeterol attenuates the inflammatory response in asthma and decreases the proinflammatory cytokine secretion of dendritic cells. Cell Mol Immunol. 2012;9(3):267-75.

54. Cho J-W, Lee K-S, Kim C-W. Curcumin attenuates the expression of IL-1 $\beta$, IL-6, and TNF-a as well as cyclin E in TNF-a-treated HaCaT cells; NF-KB and MAPKs as potential upstream targets. Int J Mol Med. 2007;19(3):469-74.

55. Peek EJ, Richards DF, Faith A, Lavender P, Lee TH, Corrigan CJ, et al. Interleukin-10-secreting "regulatory" T cells induced by glucocorticoids and $\beta 2$-agonists. Am J Respir Cell Mol Biol. 2005;33(1):105-11. 
56. Maris NA, Sluijs KFvd, Florquin S, Vos AFd, Pater JM, Jansen HM, et al. Salmeterol, a $\beta 2$-receptor agonist, attenuates lipopolysaccharideinduced lung inflammation in mice. Am J Physiol Lung Cell Mol Physiol. 2004;286(6):L1122-L8.

57. Ağaç D, Estrada LD, Maples R, Hooper LV, Farrar JD. The $\beta 2$-adrenergic receptor controls inflammation by driving rapid IL-10 secretion. Brain Behav Immun. 2018;74:176-85.

58. Miyata M, Lee J-Y, Susuki-Miyata S, Wang WY, Xu H, Kai H, et al. Glucocorticoids suppress inflammation via the upregulation of negative regulator IRAK-M. Nat Commun. 2015;6(1):6062.

59. Dong J, Li J, Cui L, Wang Y, Lin J, Qu Y, et al. Cortisol modulates inflammatory responses in LPS-stimulated RAW264.7 cells via the NF-KB and MAPK pathways. BMC Vet Res. 2018;14(1):30.

60. Mozo L, Suárez A, Gutiérrez C. Glucocorticoids up-regulate constitutive interleukin-10 production by human monocytes. Clin Exp Allergy. 2004;34(3):406-12.

61. Rüdiger JJ, Gencay M, Yang JQ, Bihl M, Tamm M, Roth M. Fast beneficial systemic anti-inflammatory effects of inhaled budesonide and formoterol on circulating lymphocytes in asthma. Respirology. 2013;18(5):840-7.

62. Fragaki K, Kileztky C, Trentesaux C, Zahm J-M, Bajolet O, Johnson M, et al. Downregulation by a long-acting $\beta 2$-adrenergic receptor agonist and corticosteroid of Staphylococcus aureus-induced airway epithelial inflammatory mediator production. Am J Physiol Lung Cell Mol Physiol. 2006;291(1):L11-L8.

63. Feng E, Wan R, Yang S, Yan Z, Wang S, He W, et al. Expression levels of induced sputum IL-8 and IL-10 and drug intervention effects in patients with acute exacerbated COPD complicated with chronic cor pulmonale at high altitude. Exp Ther Med. 2013;6(3):747-52.

64. Jeon S-Y, Hwang K-A, Choi K-C. Effect of steroid hormones, estrogen and progesterone, on epithelial mesenchymal transition in ovarian cancer development. J Steroid Biochem Mol Biol. 2016;158:1-8.

65. Risch HA. Hormonal etiology of epithelial ovarian cancer, with a hypothesis concerning the role of androgens and progesterone. J Natl Cancer Inst. 1998;90(23):1774-86.

66. Villa A, Rizzi N, Vegeto E, Ciana P, Maggi A. Estrogen accelerates the resolution of inflammation in macrophagic cells. Sci Rep. 2015;5(1):15224.

67. Ho S-M. Estrogen, progesterone and epithelial ovarian cancer. Reprod Biol Endocrinol. 2003;1(1):73.

68. Zhou Z, Bian C, Luo Z, Guille C, Ogunrinde E, Wu J, et al. Progesterone decreases gut permeability through upregulating occludin expression in primary human gut tissues and Caco-2 cells. Sci Rep. 2019;9(1):8367.

69. Mizushima T, Miyamoto H. The role of androgen receptor signaling in ovarian cancer. Cells. 2019;8(2):176.

70. Silva EG, Tornos C, Fritsche HA, el-Naggar A, Gray K, Ordonez NG, et al. The induction of benign epithelial neoplasms of the ovaries of guinea pigs by testosterone stimulation: a potential animal model. Mod Pathol. 1997;10(9):879-83.

71. Traish A, Bolanos J, Nair S, Saad F, Morgentaler A. Do androgens modulate the pathophysiological pathways of inflammation? Appraising the contemporary evidence. Clin Med. 2018;7(12):549.

72. Ebeid TA, Eid YZ, El-Abd EA, El-Habbak MM. Effects of catecholamines on ovary morphology, blood concentrations of estradiol-17 $\beta$, progesterone, zinc, triglycerides and rate of ovulation in domestic hens. Theriogenology. 2008;69(7):870-6.

73. Unsicker K, Seidel F, Hofmann H-D, Müller T, Schmidt R, Wilson A. Catecholaminergic innervation of the chicken ovary. Cell Tissue Res. $1983 ; 230(2): 431-50$.

74. Breuiller M, Tahri-Joutei A, Ferré F, Pointis G. $\beta$-Adrenergic receptors and stimulatory effects of (-) isoproterenol on testosterone production in fetal mouse Leydig cells. Biochem Biophys Res Commun. 1988;151(3):1454-60.

75. Swartz SR, Moberg GP. Effects of epinephrine, norepinephrine, and dopamine on gonadotropin-releasing hormone-induced secretion of luteinizing hormone in vitro*. Endocrinology. 1986;118(6):2425-31.

76. Tilbrook AJ, Turner Al, Clarke IJ. Effects of stress on reproduction in non-rodent mammals: the role of glucocorticoids and sex differences. Rev Reprod. 2000;5(2):105-13.

77. Barbosa ACS, Feng Y, Yu C, Huang M, Xie W. Estrogen sulfotransferase in the metabolism of estrogenic drugs and in the pathogenesis of diseases. Expert Opin Drug Metab Toxicol. 2019;15(4):329-39.

78. Tetsuka M. Actions of glucocorticoid and their regulatory mechanisms in the ovary. Anim Sci J. 2007;78(2):112-20.

79. Charbonneau B, Goode EL, Kalli KR, Knutson KL, Derycke MS. The immune system in the pathogenesis of ovarian cancer. Crit Rev Immunol. 2013;33(2):137-64.

80. Hainaut P, Plymoth A. Targeting the hallmarks of cancer: towards a rational approach to next-generation cancer therapy. Curr Opin Oncol. 2013;25(1):50-1.

81. Yin X, Wu L, Yang H, Yang H. Prognostic significance of neutrophil-lymphocyte ratio (NLR) in patients with ovarian cancer: A systematic review and meta-analysis. Medicine (Baltimore). 2019;98(45):e17475-e.

Page $12 / 20$ 
82. Williams KA, Labidi-Galy SI, Terry KL, Vitonis AF, Welch WR, Goodman A, et al. Prognostic significance and predictors of the neutrophil-tolymphocyte ratio in ovarian cancer. Gynecol Oncol. 2014;132(3):542-50.

83. Velthove KJ, Leufkens HGM, Souverein PC, Schweizer RC, Bracke M, van Solinge WW. Effects of glucocorticoids on the neutrophil count: A cohort study among hospitalized patients. Pulm Pharmacol Ther. 2010;23(2):129-34.

84. Saffar AS, Ashdown H, Gounni AS. The molecular mechanisms of glucocorticoids-mediated neutrophil survival. Curr Drug Targets. 2011;12(4):556-62.

85. Rozkova D, Horvath R, Bartunkova J, Spisek R. Glucocorticoids severely impair differentiation and antigen presenting function of dendritic cells despite upregulation of Toll-like receptors. J Allergy Clin Immunol. 2006;120(3):260-71.

86. Greenstein S, Ghias K, Krett NL, Rosen ST. Mechanisms of Glucocorticoid-mediated Apoptosis in Hematological Malignancies. Clin Cancer Res. 2002;8(6):1681-94.

87. Nishida Y, Hosomi S, Yamagami H, Sugita N, Itani S, Yukawa T, et al. Pretreatment neutrophil-to-lymphocyte ratio predicts clinical relapse of ulcerative colitis after tacrolimus induction. PloS one. 2019;14(3):e0213505-e.

88. Anderson R, Theron AJ, Steel HC, Durandt C, Tintinger GR, Feldman C. The beta-2-adrenoreceptor agonists, Formoterol and Indacaterol, but Not Salbutamol, effectively suppress the reactivity of human neutrophils in vitro. Mediators Inflamm. 2014;2014:105420.

89. Brunskole Hummel I, Reinartz MT, Kälble S, Burhenne H, Schwede F, Buschauer A, et al. Dissociations in the effects of $\beta 2$-adrenergic receptor agonists on cAMP formation and superoxide production in human neutrophils: support for the concept of functional selectivity. PloS one. 2013;8(5):e64556-e.

90. Silva RL, Castanheira FV, Figueiredo JG, Bassi GS, Ferreira SH, Cunha FQ, et al. Pharmacological beta-adrenergic receptor activation attenuates neutrophil recruitment by a mechanism dependent on nicotinic receptor and the spleen. Inflammation. 2016;39(4):1405-13.

91. Ye Z, Ai X, Liao Z, You C, Cheng Y. The prognostic values of neutrophil to lymphocyte ratio for outcomes in chronic obstructive pulmonary disease. Medicine (Baltimore). 2019;98(28):e16371-e.

92. Bullone M, Vargas A, Elce Y, Martin JG, Lavoie J-P. Fluticasone/salmeterol reduces remodelling and neutrophilic inflammation in severe equine asthma. Sci Rep. 2017;7(1):8843.

93. Zaenker P, Gray ES, Ziman MR. Autoantibody Production in Cancer-The Humoral Immune Response toward Autologous Antigens in Cancer Patients. Autoimmun Re. 2016;15(5):477-83.

94. Zhang J-Y, Tan EM. Autoantibodies to tumor-associated antigens as diagnostic biomarkers in hepatocellular carcinoma and other solid tumors. Expert Rev Mol Diagn. 2010;10(3):321-8.

95. Karen S. A, Daniel W. C, Sahar S, Garrick W, Jessica W, Jin P, et al. Autoantibody signature for the serologic detection of ovarian cancer. J Proteome Res. 2015; 14(1): 578-586.

96. Ruhaak LR, Kim K, Stroble C, Taylor SL, Hong Q, Miyamoto S, et al. Protein-specific differential glycosylation of immunoglobulins in serum of ovarian cancer patients. J Proteome Res. 2016;15(3):1002-10.

97. Staff C, Magnusson CGM, Hojjat-Farsangi M, Mosolits S, Liljefors M, Frödin J-E, et al. Induction of IgM, IgA and IgE antibodies in colorectal cancer patients vaccinated with a recombinant CEA protein. J Allergy Clin Immunol. 2012;32(4):855-65.

98. Manjula S, Aroor A, Raja A, Rao S, Rao A. Serum immunoglobulins in brain tumours. Acta Neurochir. 1992;115(3-4):103-5.

99. Qiu X, Zhu X, Zhang L, Mao Y, Zhang J, Hao P, et al. Human epithelial cancers secrete immunoglobulin G with unidentified specificity to promote growth and survival of tumor cells. Cancer Res. 2003;63(19):6488-95.

100. Hou YY, Suzuki Y, Aida K. Effects of steroid hormones on immunoglobulin M (IgM) in rainbow trout, Oncorhynchus mykiss. Fish Physiol Biochem. 1999;20(2):155-62.

101. Benko AL, Olsen NJ, Kovacs WJ. Glucocorticoid inhibition of activation-induced cytidine deaminase expression in human B lymphocytes. Mol Cell Endocrinol. 2014;382(2):881-7.

102. Lee J, Machin M, Russell KE, Pavlidis S, Zhu J, Barnes PJ, et al. Corticosteroid modulation of immunoglobulin expression and B-cell function in COPD. FASEB J. 2016;30(5):2014-26.

103. Manzoni D, Catallo R, Chebel A, Baseggio L, Michallet A-S, Roualdes O, et al. The ibrutinib B-cell proliferation inhibition is potentiated in vitro by dexamethasone: Application to chronic lymphocytic leukemia. Leuk Res. 2016;47:1-7.

104. Sanders VM. The beta2-adrenergic receptor on T and B lymphocytes: Do we understand it yet?. Brain Behav Immun. 2012;26(2):195-200.

105. Duffy DM, Ko C, Jo M, Brannstrom M, Curry TE, Jr. Ovulation: parallels with inflammatory processes. Endocr Rev. 2018;40(2):369-416.

106. Dupont J, Scaramuzzi RJ, Reverchon M. The effect of nutrition and metabolic status on the development of follicles, oocytes and embryos in ruminants. Animal. 2014;8(7):1031-44.

107. Holesh JE, Bass AN, Lord M. Physiology, ovulation. StatPearls [Internet]. 2020. 
108. Liu L, Song Z, Sheikhahmadi A, Jiao H, Lin H. Effect of corticosterone on gene expression of feed intake regulatory peptides in laying hens. Comparative Biochemistry and Physiology Part B: Biochem Mol Biol Educ. 2012;162(4):81-7.

109. Hatefi A, Towhidi A, Zali A, Zeinoaldini S, Ganjkhanlou M, Plascencia A. Effects of dietary zilpaterol hydrochloride ( $\beta 2$-agonist) supplementation on finishing castrated male goats: metabolic endocrine, blood constituents, plasma volume, respiratory rate and cardiac changes. J Appl Anim Res. 2017;45(1):447-53.

110. Beitzel F, Lynch GS. $\beta$-Adrenergic stimulation enhances IGF signaling in regenerating rat skeletal muscle. The FASEB J. 2007;21(6):A944-A.

111. Krieg RJ, Perkins SN, Johnson JH, Rogers JP, Arimura A, Cronin MJ. $\beta$-adrenergic stimulation of growth hormone (GH) release in vivo, and subsequent inhibition of gh releasing factor-induced GH secretion*. Endocrinology. 1988;122(2):531-7.

112. Andrews RC, Walker BR. Glucocorticoids and insulin resistance: old hormones, new targets. Clin Sci (London, England : 1979). 1999;96(5):513-23.

113. Viveiros MM, Liptrap RM. Glucocorticoid influence on porcine granulosa cell IGF-I and steroid hormone production in vitro. Theriogenology. 1999;51(6):1027-43.

114. Giustina A, Wehrenberg WB. The role of glucocorticoids in the regulation of growth hormone secretion Mechanisms and clinical significance. Trends Endocrinol Metab. 1992;3(8):306-11.

115. Gross WB, Siegel HS. Evaluation of the heterophil/lymphocyte ratio as a measure of stress in chickens. Avian Dis. 1983;27(4):972-9.

116. Onbaşılar EE, Aksoy FT. Stress parameters and immune response of layers under different cage floor and density conditions. Livest Prod Sci. 2005;95(3):255-63.

\section{Tables}

Table 1

The Ingredients (\%) and nutrient composition of the diet

\begin{tabular}{|ll|}
\hline Diets & Value (\%) \\
\hline Corn & 61.00 \\
\hline Soybean meal & 23.45 \\
\hline Sodium bicarbonate & 0.05 \\
\hline D-calcium phosphate & 1.53 \\
\hline fatty acid & 2.81 \\
\hline Salt & 0.07 \\
\hline Calcium carbonate & 10.47 \\
\hline Vitamins + Minerals & 0.50 \\
\hline DL-methionine & 0.13 \\
\hline Calculated analysis & \\
\hline Crude protein & 15.39 \\
\hline Calcium & 4.62 \\
\hline Available phosphorus & 0.40 \\
\hline Metabolizable energy & $2780^{*}$ \\
\hline
\end{tabular}

* $(\mathrm{kcal} / \mathrm{kg})$ 
Table 2

Chicken primers used for real-time PCR

\begin{tabular}{|c|c|c|c|}
\hline Gene & Accession No. & primers sequences $\left(5^{\prime} \rightarrow 3^{\prime}\right)$ & Orientation \\
\hline \multirow[t]{2}{*}{$\operatorname{cox} 2$} & \multirow[t]{2}{*}{ XM_422297 } & СTGCTСССТСССАTGTCAGA & Forward \\
\hline & & CACGTGAAGAATTCCGGTGTT & Reverse \\
\hline \multirow[t]{2}{*}{ TNF-a } & \multirow[t]{2}{*}{ AY765397 } & TGTGTATGTGCAGCAACCCGTAGT & Forward \\
\hline & & GGCATTGCAATTTGGACAGAAGT & Reverse \\
\hline \multirow[t]{2}{*}{ IL-1B } & \multirow[t]{2}{*}{ AB559570 } & СТTССTСCAGCCAGAAAGT & Forward \\
\hline & & CAGCTTGTAGCCCTTGAT & Reverse \\
\hline \multirow[t]{2}{*}{ IL-10 } & \multirow[t]{2}{*}{ AB559574 } & САСААСTTСTTСАССTGCGAG & Forward \\
\hline & & CATGGCTTTGTAGATCCCGTTC & Reverse \\
\hline \multirow[t]{2}{*}{ IL-6 } & \multirow[t]{2}{*}{ AB559572 } & СААССТСААССТGСССАА & Forward \\
\hline & & GGAGAGCTTCCTCAGGCATT & Reverse \\
\hline \multirow[t]{2}{*}{$\beta 2$ adrenergic receptor } & \multirow[t]{2}{*}{ XM_004950587 } & GACGCCGGAACGCTGAG & Forward \\
\hline & & GAAGACAGTGACCAGCACGA & Reverse \\
\hline \multirow[t]{2}{*}{ cox1 } & \multirow[t]{2}{*}{ XM_425326 } & TCAGGTGGTTCTGGGACATCA & Forward \\
\hline & & TGTAGCCGTACTGGGAGTTGAA & Reverse \\
\hline \multirow[t]{2}{*}{$\beta$-Actin } & \multirow[t]{2}{*}{ L08165 } & CATCACCATTGGCAATGAGAGG & Forward \\
\hline & & GCAAGCAGGAGTACGATGAATC & Reverse \\
\hline
\end{tabular}

Table 3

The comparison of hen's ovulation rate and follicular sizes F1 to F5 in control and treated groups (mean \pm SD)

\begin{tabular}{|c|c|c|c|c|c|c|c|c|c|}
\hline & Control & BAA $^{2}$ & $G C^{3}$ & $\mathrm{GC}+\mathrm{BAA}^{4}$ & $\mathrm{GC}+\mathrm{BAA}^{5}$ & $\mathrm{GC}+\mathrm{BAA}^{6}$ & $\mathrm{BB}^{7}$ & SEM $^{8}$ & $\begin{array}{l}\text { p- } \\
\text { value }\end{array}$ \\
\hline $\begin{array}{l}\text { Ovulation } \\
\text { rate }^{1}(\%)\end{array}$ & $\begin{array}{l}61.05 \pm 8.93^{9} \\
b\end{array}$ & $72.15 \pm 8.89^{a}$ & $33.89 \pm 10.27^{c}$ & $32.21 \pm 10.21^{\mathrm{c}}$ & $31 \pm 10.47^{c}$ & $36.29 \pm 8.86^{c}$ & $67.3 \pm 9.97^{a}$ & 2.9 & $<0.05$ \\
\hline \multicolumn{10}{|l|}{$\begin{array}{l}\text { Follicular } \\
\text { size }\end{array}$} \\
\hline $\begin{array}{l}\text { Follicle } \\
\text { F1 (mm) }\end{array}$ & $27.85 \pm 5.39^{a}$ & $32.4 \pm 0.32^{a}$ & $6.25 \pm 5.39^{d}$ & $24.51 \pm 7.67^{b, c}$ & $24 \pm 9.05^{b, c}$ & $29.5 \pm 3.78^{a}$ & $30.52 \pm 2.24^{a}$ & 2.06 & $<0.01$ \\
\hline $\begin{array}{l}\text { Follicle } \\
\text { F2 (mm) }\end{array}$ & $27.25 \pm 3.15^{\mathrm{a}}$ & $27.52 \pm 3.05^{a}$ & N.O ${ }^{10}$ & $22.3 \pm 5.93^{a}$ & $21.81 \pm 1.57^{a}$ & $27.98 \pm 5.39^{a}$ & $25.24 \pm 6.39^{a}$ & 2.05 & 0.188 \\
\hline $\begin{array}{l}\text { Follicle } \\
\text { F3 (mm) }\end{array}$ & $20.77 \pm 4.4^{a}$ & $23.33 \pm 4.5^{a}$ & N.O & $16.9 \pm 1.81^{a}$ & $21.19 \pm 2.39^{a}$ & $22.39 \pm 2.97^{a}$ & $20.08 \pm 3.66^{a}$ & 1.93 & 0.7 \\
\hline $\begin{array}{l}\text { Follicle } \\
\text { F4 (mm) }\end{array}$ & $15.62 \pm 4.31^{\mathrm{a}}$ & $19.37 \pm 2.74^{a}$ & N.O & $13.21 \pm 1.03^{a}$ & $15.92 \pm 4.61^{a}$ & $18.08 \pm 3.8^{a}$ & $15.71 \pm 4^{a}$ & 1.77 & 0.44 \\
\hline $\begin{array}{l}\text { Follicle } \\
\text { F5 (mm) }\end{array}$ & $11.38 \pm 2.02^{a}$ & $13.43 \pm 1.18^{a}$ & N.O & N.O & $11.61 \pm 1.01^{a}$ & $14.63 \pm 0.59^{a}$ & $9.85 \pm 2.11^{a}$ & 1.34 & 0.62 \\
\hline
\end{tabular}

1) Egg laying frequency, 2) Beta-2 adrenergic agonist (Salmeterol, 1 ppm), 3) Glucocorticoid (Fluticasone, 2 ppm), 4) 2 ppm Fluticasone+ $0.5 \mathrm{ppm}$ Salmeterol $(4: 1), 5) 2 \mathrm{ppm}$ Fluticasone+ 1ppm Salmeterol $(2: 1), 6) 2$ ppm Fluticasone+ 2ppm Salmeterol (1:1), and 7) Beta blocker (Propranolol), 8) Standard error of the mean, 9) Standard deviation (SD), and 10) Not observed. Different statistical letters (a-d) are significant $(p<0.05)$ according to the Duncan's multiple range test.

\section{Figures}



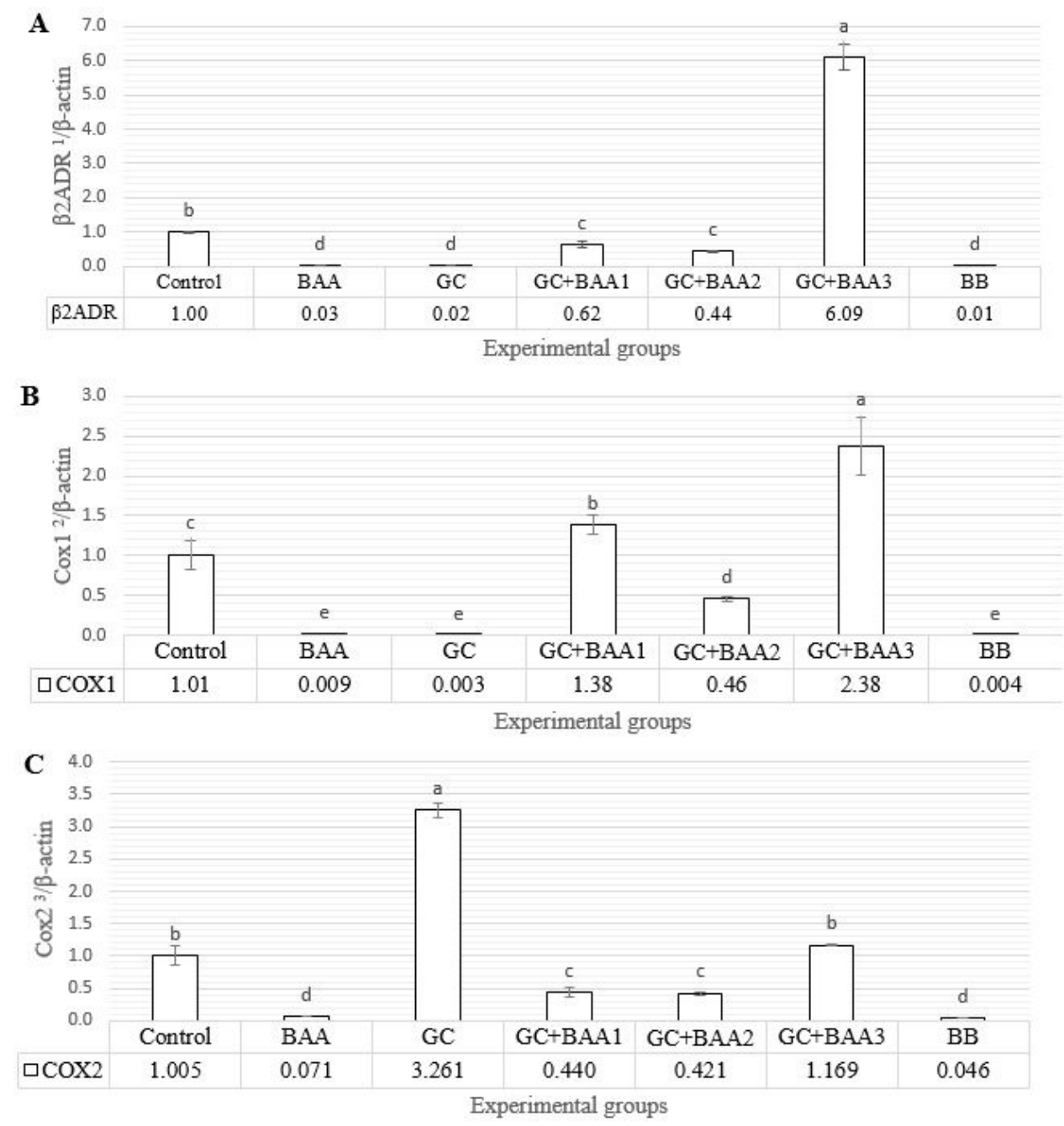

\section{Figure 1}

The comparison of $\beta 2 A D R(A), C O X-1$ (B), and COX-2 (C) mRNA expression between control and treated groups. $\beta 2 A D R$, COX-2, and COX-2 mRNA data that are normalized by $\beta$-actin. (BAA) Beta-2 adrenergic agonist (Salmeterol, 1 ppm), (GC) Glucocorticoid (Fluticasone, 2 ppm), (GC + BAA1) 2 ppm Fluticasone+0.5ppm Salmeterol (4:1), (GC+BAA2) 2 ppm Fluticasone+1ppm Salmeterol (2:1), (GC+BAA3) 2 ppm Fluticasone+2ppm Salmeterol (1:1), and (BB) Beta blocker (Propranolol), Different statistical letters (a-e) are significant $(\mathrm{p}<0.05)$ according to the Duncan's multiple range test. 1) Beta-2 adrenergic receptor, 2) Cyclooxygenases-1, and 3) Cyclooxygenases-2. 

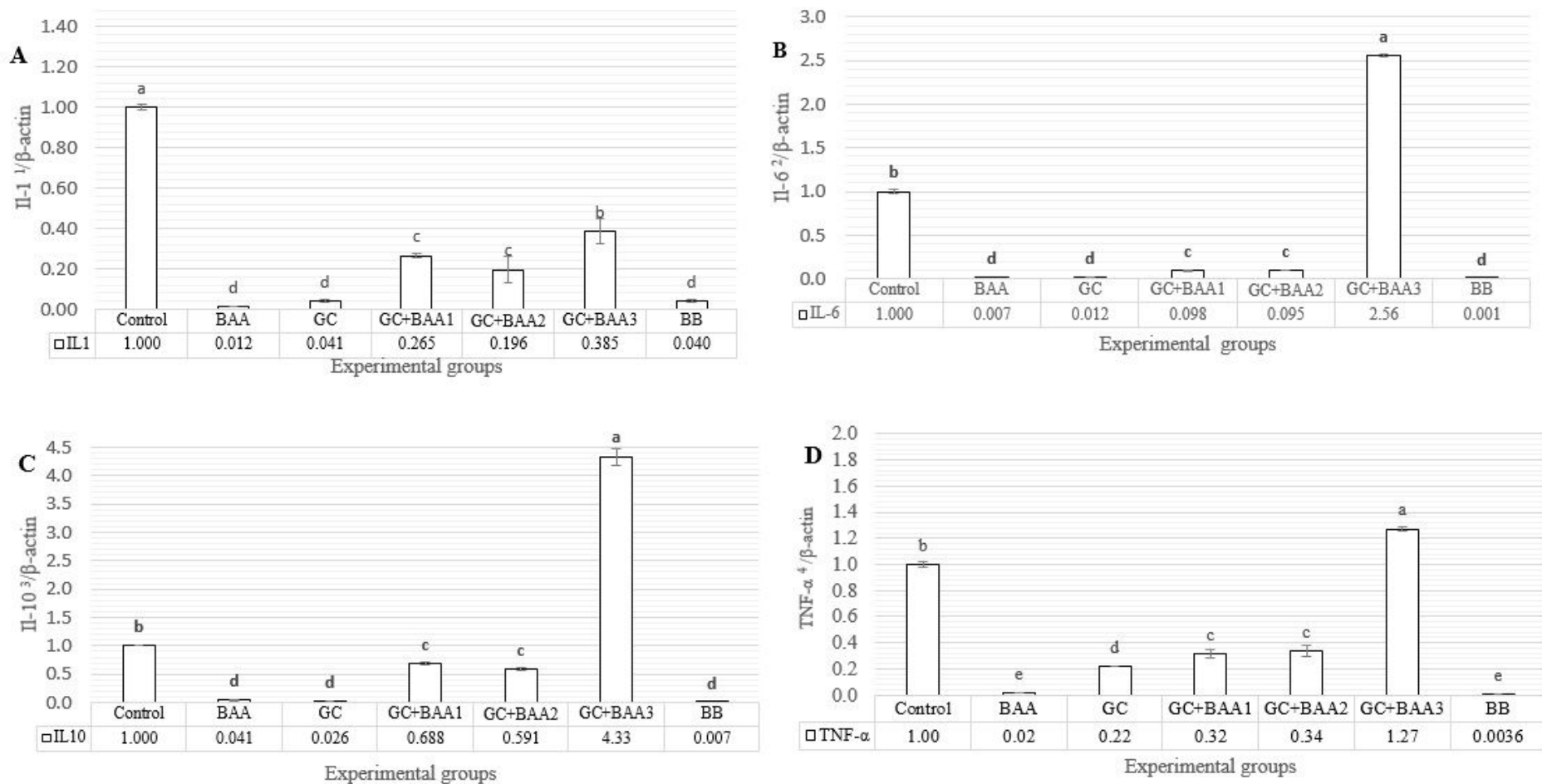

\section{Figure 2}

The comparison of IL-1 $\beta$ (A), IL-6 (B), IL-10 (C) and TNF- $\alpha$ (D) mRNA expression between control and treated groups. IL-1 $\beta$, IL-6, IL-10 and TNF- $a$ mRNA are normalized by $\beta$-actin. (BAA) Beta-2 adrenergic agonist (Salmeterol, 1 ppm), (GC) Glucocorticoid (Fluticasone, 2 ppm), (GC + BAA1) 2 ppm Fluticasone+0.5ppm Salmeterol (4:1), (GC+BAA2) 2 ppm Fluticasone+1ppm Salmeterol (2:1), (GC+BAA3) 2 ppm Fluticasone+2ppm Salmeterol (1:1), and (BB) Beta blocker (Propranolol), Different statistical letters (a-e) are significant ( $<<0.05)$ according to the Duncan's multiple range test. 1) Interleukin-1 $\beta, 2$ ) Interleukin -6, 3) Interleukin -10, and 4) Tumor necrosis factor-a 
A
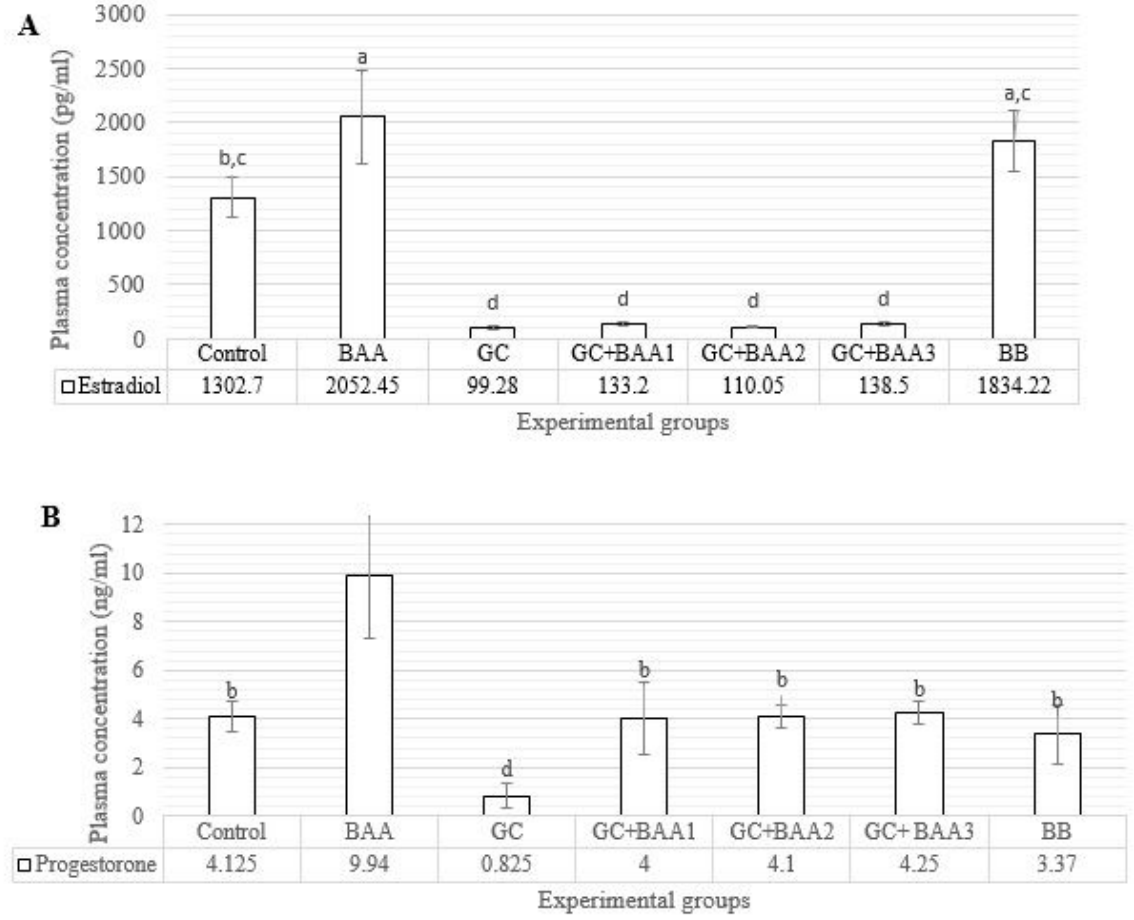

C

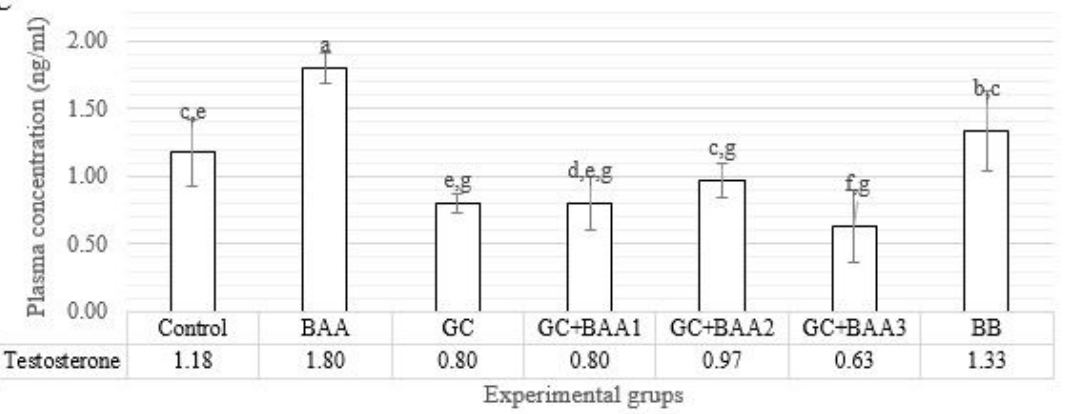

Figure 3

The comparison of plasma Estradiol (A), Progesterone (B and Testosterone (C) contents between control and treated groups. (BAA) Beta-2 adrenergic agonist (Salmeterol, 1 ppm), (GC) Glucocorticoid (Fluticasone, 2 ppm), (GC+BAA1) 2 ppm Fluticasone+0.5ppm Salmeterol (4:1), (GC+BAA2) 2 ppm Fluticasone+1ppm Salmeterol (2:1), (GC+BAA3) 2 ppm Fluticasone+2ppm Salmeterol (1:1), and (BB) Beta blocker (Propranolol), Different statistical letters $(a-g)$ are significant $(p<0.05)$ according to the Duncan's multiple range test. 

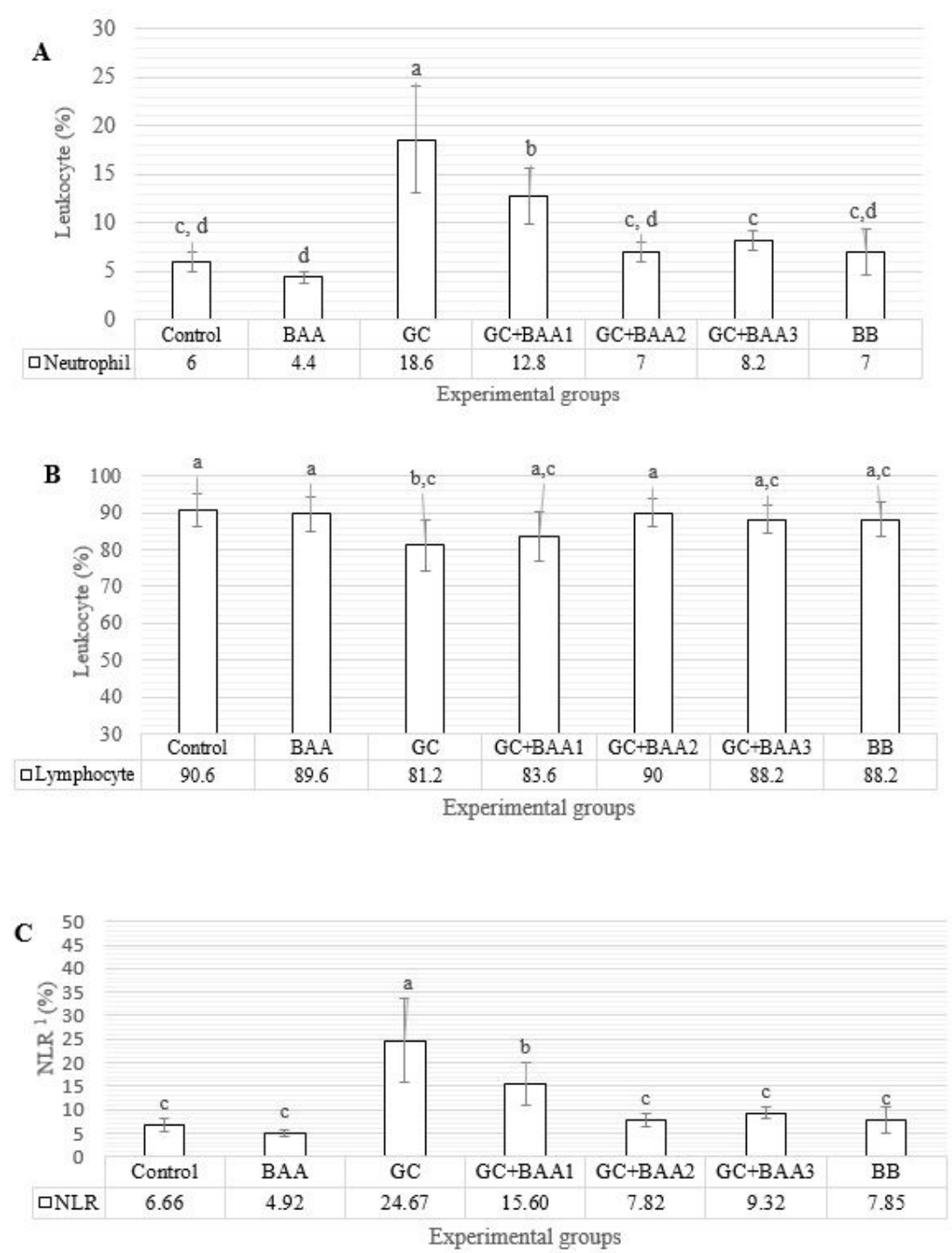

\section{Figure 4}

The comparison of heterophil (neutrophil) (A), Llymphocyte (B), and heterophile: lymphocyte Percentages (C) between control and treated groups. (BAA) Beta-2 adrenergic agonist (Salmeterol, 1 ppm), (GC) Glucocorticoid (Fluticasone, 2 ppm), (GC + BAA1) 2 ppm Fluticasone+0.5ppm Salmeterol (4:1), (GC+BAA2) 2 ppm Fluticasone+1ppm Salmeterol (2:1), (GC+BAA3) 2 ppm Fluticasone+2ppm Salmeterol (1:1), and (BB) Beta blocker (Propranolol), Different statistical letters $(a-d)$ are significant $(p<0.05)$ according to the Duncan's multiple range test. 1) neutrophilelymphocyte ratio.

Humoral Immunities

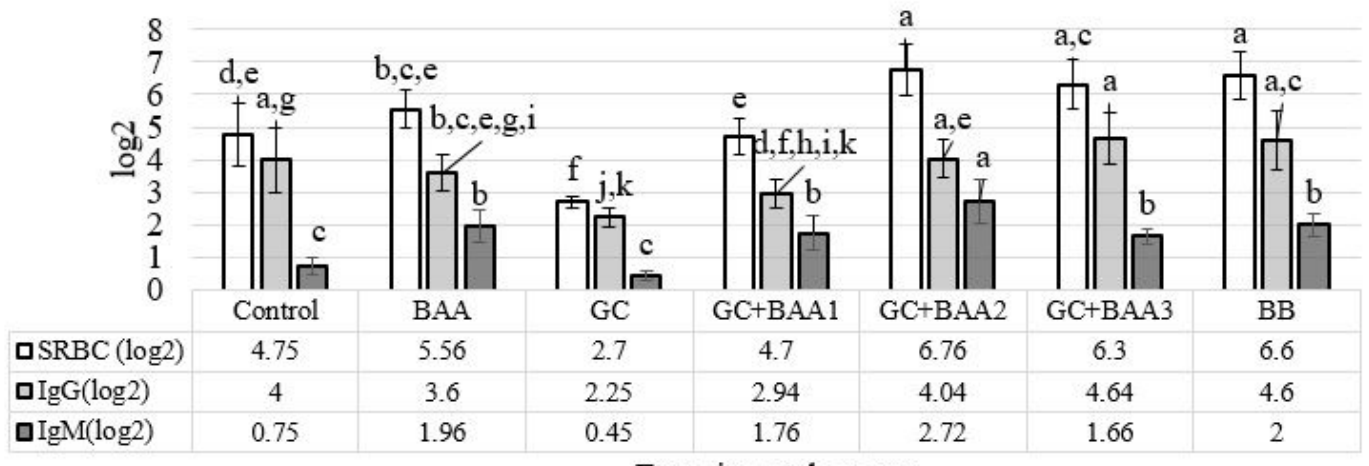

Experimental groups 
The comparison of whole immunoglobulin (Ig, SRBC), IgG, and IgM contents between control and treated groups. (BAA) Beta-2 adrenergic agonist (Salmeterol, 1 ppm), (GC) Glucocorticoid (Fluticasone, 2 ppm), (GC + BAA1) 2 ppm Fluticasone+0.5ppm Salmeterol (4:1), (GC+BAA2) 2 ppm Fluticasone+1 ppm Salmeterol (2:1), (GC+BAA3) 2 ppm Fluticasone+2ppm Salmeterol (1:1), and (BB) Beta blocker (Propranolol), Different statistical letters $(a-k)$ are significant $(p<0.05)$ according to the Duncan's multiple range test.

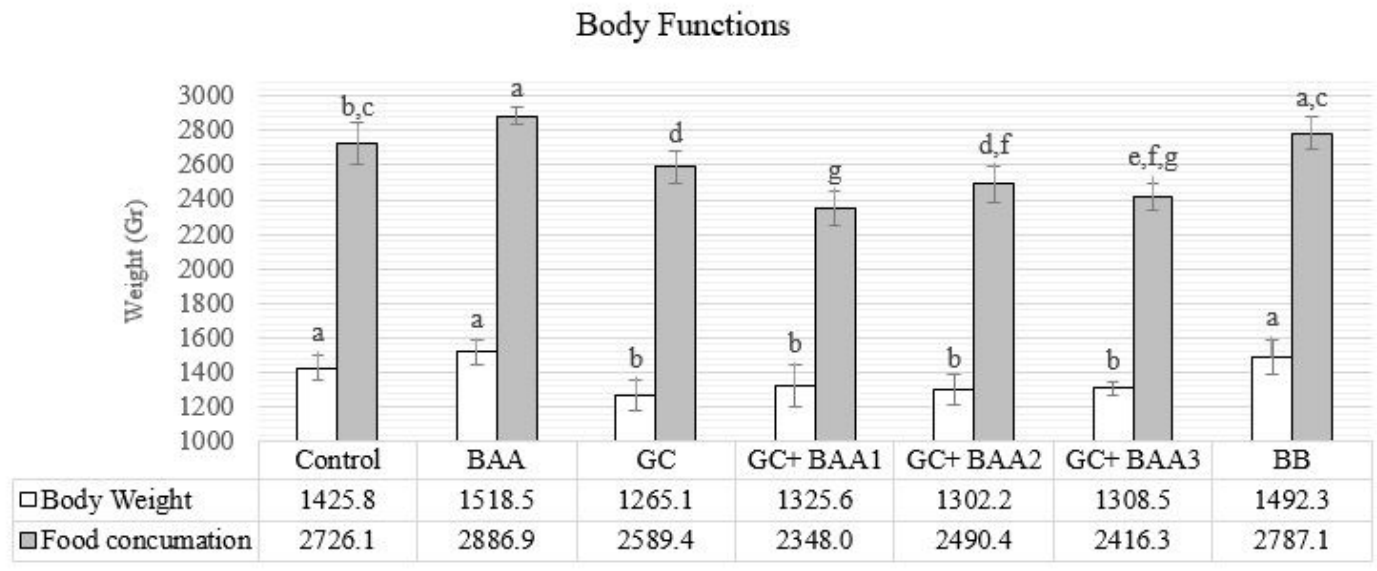

\section{Figure 6}

The comparison of body weight and food consummation between control and treated groups. (BAA) Beta-2 adrenergic agonist (Salmeterol, 1 ppm), (GC) Glucocorticoid (Fluticasone, 2 ppm), (GC + BAA1) 2 ppm Fluticasone+0.5ppm Salmeterol (4:1), (GC+BAA2) 2 ppm Fluticasone+1ppm Salmeterol (2:1), (GC+BAA3) 2 ppm Fluticasone+2ppm Salmeterol (1:1), and (BB) Beta blocker (Propranolol), Different statistical letters (a-g) are significant $(p<0.05)$ according to the Duncan's multiple range test. 